\title{
DA FORMAÇÃO CULTURAL À MOBILIZAÇÃO SOCIAL: ESPAÇOS DE FORMAÇÃO E MOBILIZAÇẪO AO LONGO DE TRÊS GERAÇÕES NAS PERIFERIAS DE SÃO PAULO
}

Leonardo de Oliveira Fontes

Pós-doutorando de Sociologia do Centro Brasileiro de Análise e Planejamento (Cebrap).

SãoPaulo,SP, Brasil. leo.ofontes@gmail.com

Orcid: 0000-0001-9686-7597

http://dx.doi.org/10.1590/0102-051101/109

\section{Introdução}

Em seu clássico trabalho sobre ação coletiva From Mobilization to Revolution Charles Tilly (1978, p. 5) argumenta que o campo de estudo dos movimentos sociais estaria focado nas "formas como as pessoas agem conjuntamente em busca de interesses compartilhados". Com isso, ele defende a existência de cinco componentes da análise da ação coletiva e que, portanto, deveriam ser objeto de pesquisas sobre o tema: interesse, organização, mobilização, oportunidade e a ação coletiva propriamente dita.

Tilly estava ciente das consequências de suas escolhas metodológicas. Ao priorizar movimentos sociais relativamente bem definidos e suas relações com a esfera institucional de poder - o Estado -, ele sabia que estava negligenciando duas ordens de questões definidas por ele mesmo como "fascinantes": como se formam novos grupos orientados por novas visões de mundo e sob que condições grupos mal definidos de pessoas, como um grupo de amigos, se tornam atores relevantes da ação coletiva. 
O que este trabalho se propõe a fazer é justamente inverter as prioridades que vêm sendo adotadas pela sociologia dos movimentos sociais e colocar luz sobre as questões que Tilly, e toda uma linhagem de autores posteriores, acabou por deixar de lado ao analisar as ações coletivas em diferentes contextos sociais. Assim, o que se pretende aqui é dar um passo atrás em relação ao que tradicionalmente se entende como análise dos movimentos sociais e da ação coletiva a fim de compreender como, a partir das experiências e das perspectivas dos atores, se forma uma "cultura pública" (Cefaï, 2009, p. 27), isto é, “o fundo comum que dá forma e material às mobilizações coletivas”. Dessa forma, o desafio que se propõe aqui será o de "descrever a mutação das experiências coletivas e dos meios institucionais, fazendo-os emergir das atividades enquanto estas se realizam" (Cefaï, 2009, p. 16).

Para tanto, além de explorar as mudanças históricas em termos de repertórios de ação, o objetivo deste artigo é analisar as conexões entre o modo de vida (Thompson, 1966), espaços de deliberações e formação política - aqui chamadas de esferas públicas subalternas (Fraser, 1990; Perlatto, 2015) - e ações coletivas nas periferias de São Paulo por três diferentes gerações. ${ }^{1}$ Cumpre esclarecer que o movimento do artigo e da pesquisa na qual ele se baseia não teve a pretensão de identificar quais seriam as tendências predominantes em termos de subjetividade nas periferias em cada período histórico, mas de analisar, entre as pessoas que se engajaram politicamente, quais foram os espaços e experiências que possibilitaram a formação política que alicerçou esse engajamento.

O material que embasa esta pesquisa foi colhido por meio de uma pesquisa de campo na periferia de São Paulo,

\footnotetext{
1 Compreende-se a ideia de "geração", conforme Mannheim (1952), não como um dado cronológico, mas a partir da existência de influências similares que afetam as experiências dos sujeitos. Com isso, "o intervalo de tempo que separa as gerações torna-se subjetivamente experienciável; e a contemporaneidade se torna uma condição subjetiva de ter sido submetido às mesmas influências determinantes" (Mannheim, 1952, p. 282, tradução nossa).
} 
mais especificamente nos distritos de Jardim Ângela, na zona sul, e Brasilândia, na zona norte. Nessas regiões foi realizada entre início de 2015 e fim de 2016 uma pesquisa que combinou métodos etnográficos - observação participante, conversas informais e entrevistas em profundidade com dados quantitativos, ${ }^{2}$ além da consulta a documentos e textos que já se debruçaram sobre as periferias paulistanas em outros momentos. Os dados colhidos foram analisados seguindo o que Burawoy (1998) denomina "método do caso estendido", que busca aplicar a ciência reflexiva à etnografia a fim de extrair o geral do particular e conectar o presente com o passado em antecipação do futuro a partir da teoria existente.

Este texto está dividido em outras quatro partes, além desta introdução e de uma seção para considerações finais. Na seção imediatamente seguinte, serão trabalhados os pressupostos teóricos que embasam essa análise e que buscam combinar questões trazidas pela tradição da teoria crítica com um referencial gramsciano vindo dos chamados estudos subalternos e dos estudos culturais ingleses, além de ponderações trazidas pelo pragmatismo francês.

Cada uma das três partes seguintes corresponde a uma das gerações aqui analisadas dentro do contexto político e social daquele período. Na terceira seção, será explorada a experiência daqueles que migraram para São Paulo em busca de melhores condições de inserção econômica e constituíram, a partir da experiência em seus bairros e nas Comunidades Eclesiais de Base (CEB), os novos movimentos sociais que entraram em cena nas décadas de 1970 e 1980 em um contexto de autoritarismo político. Em seguida, será analisado o impacto das mudanças ocorridas nas décadas

\footnotetext{
2 Para a parte quantitativa da pesquisa foram realizadas entrevistas em 391 residências, divididas entre os dois distritos selecionados. Para essas entrevistas foram selecionadas ruas aleatoriamente e nessas ruas foi utilizado um método de entrevistar pessoas de uma a cada dez residências.
} 
de 1990 e 2000 em termos de reestruturação do mundo do trabalho, no plano econômico, de ampliação da criminalidade, no plano social, e de institucionalização dos movimentos sociais, na esfera política. Finamente, na última parte, busca-se compreender as mudanças trazidas com as possibilidades de ganhos educacionais e salariais nos últimos anos e como as novas formas de expressão cultural desenvolvidas ao longo dos anos 2000 e início da década de 2010 contribuíram para a emergência de novos sujeitos políticos bem como suas relações com as mobilizações coletivas recentes como em junho de 2013 e nas ocupações de escolas públicas no fim de 2015 .

\section{As esferas públicas subalternas e a formação de uma cultura pública}

Como anunciado anteriormente, o intuito deste texto é analisar como diferentes gerações de moradores das periferias de São Paulo construíram ou identificaram elementos comuns que serviram de pano de fundo para mobilizações coletivas mais amplas. Para isso, é preciso identificar os espaços nos quais esses sujeitos, por meio de práticas de sociabilidade, debate e deliberação, podem criticar a ordem vigente e descobrir ou criar o que seria o "bem comum" daquela comunidade.

A noção geral de esfera pública ou de espaço público, no qual se expressa uma opinião pública crítica e que ainda não conquistou o espaço público legitimado (Habermas, 1984), é útil como ponto de partida. Contudo, Fraser (1990) pontua, com razão, que a visão Habermasiana é um tanto idealizada a respeito da "esfera pública burguesa". Como bem afirma a autora, a própria ideia de esfera pública foi, desde seus primórdios, formulada de forma a excluir uma parcela significativa da sociedade, tais como mulheres, minorias étnicas e as classes trabalhadoras de maneira geral. Além disso, o próprio funcionamento dessa esfera pública em uma sociedade fortemente estratificada como a 
brasileira tende, inevitavelmente, a privilegiar os membros dos grupos dominantes que empregam com maior eficiência certos códigos, como as formas "corretas" de se portar e de falar em público, levando à reprodução de práticas comuns na sociedade como o machismo ou outras formas de discriminação social.

Com isso, Fraser (1990, p. 67) aponta a inevitável emergência do que ela denomina "contrapúblicos subalternos" (subaltern counterpublics), que historicamente contestaram as normas excludentes da esfera pública burguesa e buscaram elaborar estilos políticos e normas de discurso público alternativas. Em poucas palavras, os "contrapúblicos subalternos" seriam arenas discursivas paralelas onde membros dos grupos subordinados criam e circulam contradiscursos que lhes permitem formular interpretações opostas de suas identidades, interesses e necessidades.

Cumpre ressaltar que tais "contrapúblicos" podem ser virtuais ou presenciais, bem como podem ter caráter cultural, religioso ou explicitamente políticos. Por outro lado, eles nem sempre são virtuosos, podendo, em grande medida, reproduzir práticas de dominação e exclusão. De todo modo, tendem a expandir o espaço discursivo e, no geral, ampliam a contestação discursiva. Assim, ao invés de adotar como ideal normativo a necessária unificação dos "públicos” em uma única esfera pública, Fraser (1990) aponta que o ideal de paridade participatória seria melhor atingido por uma multiplicidade de esferas públicas do que por uma única.

Tal fato se acentua quando nos debruçamos sobre a realidade de tamanha desigualdade socioeconômica do Brasil, país em que a esfera pública, assim como o Estado e o mercado, possui um caráter eminentemente seletivo, tanto em relação a quem pode operar nela, quanto em relação aos temas debatidos (Perlatto, 2015). Dessa forma, historicamente estabeleceram-se, no Brasil, esferas públicas subalternas, "constituídas por diferentes espaços de sociabilidade 
nos quais os segmentos subalternos buscaram se organizar" (Perlatto, 2015, p. 123).

Na leitura de Perlatto (2015, p. 125), as esferas públicas subalternas se diferenciariam da visão de Fraser a respeito dos "contrapúblicos subalternos" por não colocar tanta ênfase na ideia de que "os públicos subalternos seriam necessariamente contrários à esfera pública seletiva”, ainda que possam, em alguns momentos, assumir essa perspectiva de contestação. Segundo o autor, seria equivocado defini-los apenas com base na sua oposição à esfera pública seletiva ou burguesa, como define Fraser, pois isso seria reduzir a importância da própria dinâmica interna dessas esferas públicas subalternas e das complexas relações existentes entre as diferentes esferas públicas.

É preciso, ainda, fazer jus ao conceito de subalternidade extraído dos escritos de Antonio Gramsci e pouco explorado na tradição da teoria crítica à qual, em alguma medida, 56 Fraser e Perlatto se filiam. O conceito cunhado originalmente por Gramsci foi retomado no início dos anos 1980 por um conjunto de estudiosos indianos, liderados por Ranajit Guha e, na década seguinte, difundido nos Estados Unidos e no restante do mundo, inclusive na América Latina. Com essa expansão, uma importante virada ocorre sob a influência das ideias de Derrida e Foucault, e assim amplia-se a noção de subalternidade para além da "classe trabalhadora" em direção a grupos sujeitos a variadas formas de opressão, movimento semelhante ao realizado pelos Estudos Culturais Ingleses (Liguori, 2017; Góes, 2014). O conceito, portanto, permite o entrelaçamento entre a posição social - de caráter estrutural - e a subjetividade - de caráter cultural e ideológico, algo já presente no próprio Gramsci (Liguori, 2017).

Gramsci ressalta que a história dos grupos subalternos, por estarem sob influência dos grupos dominantes, mesmo quando se rebelam, é necessariamente desagregada e episódica. Por isso, é preciso buscar em traços da cultura popular 
(Hall, 1981) os "elementos de rebeldia espontânea" desses grupos (Del Roio, 2017; Semeraro, 2017), colocando a questão do modo de vida (Thompson, 1966) desses sujeitos no centro da análise. Com isso, é possível colocar em prática dois dos postulados principais dos Estudos Subalternos: a ampliação da noção de política para além das relações com o Estado e da organização coletiva e o entendimento da consciência para além racionalidade na lógica ocidental (Modonesi, 2017).

Desse modo, se queremos entender a importância da experiência de subalternidade para o processo de subjetivação política, é preciso buscar os elementos de contestação e resistência dos grupos subalternos em seu modo de vida e nas esferas públicas subalternas. Uma vez que é nesses espaços que se formam o que Scott (1990) chama de "discursos ocultos" (hidden trasncripts) ou uma "infrapolítica dos subalternos", isto é, ações e práticas cotidianas, por meio das quais os grupos subalternos da sociedade buscam resistir à exploração material e às formas de dominação política e simbólica, de forma a manter a resistência viva, questionar os limites do permissível e fomentar valores, entendimentos e indignações. Essa infrapolítica dos subalternos, uma espécie de "infraestrutura" cultural sobre a qual outros desenvolvimentos políticos podem ocorrer, é justamente o alicerce do que Cefaï (2009, p. 27-28) chama de uma "cultura pública", isto é, "o fundo comum que dá forma e material às mobilizações coletivas".

Identificar as esferas públicas subalternas constituídas ao longo das últimas gerações nas periferias de São Paulo e a cultura pública a que elas deram lugar é o objetivo das próximas seções deste artigo.

\section{Das Comunidades Eclesiais de Base à luta por direitos: a entrada em cena da primeira geração de sujeitos políticos}

Os primeiros movimentos sociais advindos das periferias de São Paulo e que emergiram na cena púbica datam das décadas de 1970 e 1980. Nesses anos, as periferias 
paulistanas já eram habitadas por muitos imigrantes, mas seguiam recebendo um grande contingente de pessoas vindas principalmente do nordeste do país e de regiões mais pobres de Minas Gerais, mas também de outros estados, em busca de trabalho na capital paulista. ${ }^{3}$

Em linhas gerais, entre os elementos que compunham o modo de vida desses primeiros moradores das periferias e que são relevantes para o argumento aqui desenvolvido estão: (1) a busca pelo trabalho industrial como referência central de inserção produtiva (Durham, 1988) - mas que não sendo acessível à maioria das pessoas, produziu uma grande heterogeneidade de possibilidades de ocupações e níveis de renda; (2) o estabelecimento da família como espaço de formação ética e de construção de um projeto coletivo de mobilidade social, no qual a "ética do provedor" (Zaluar, 2000) se combinava com uma "ética da honestidade" (Sader, 1988) a partir da qual os filhos deveriam ser preparados para a vida adulta, com o intuito que estudassem, trabalhassem duro e não caíssem na "vida fácil" de roubos, furtos e tráfico de drogas; (3) a constituição da família como "unidade de cooperação econômica" ou "unidade de consumo" (Durham, 1978) e como contraponto "às tendências individualizadoras dominantes na vida urbana" (Sader, 1988, p. 101); (4) o estabelecimento da casa própria, em geral autoconstruída, como o grande símbolo do projeto familiar de ascensão social, cuja contrapartida pública eram os serviços públicos urbanos (Durham, 1988); (5) o desenvolvimento de uma dinâmica de vida "comunitária”, na qual

\footnotetext{
${ }^{3}$ Apesar de uma considerável redução no fluxo de imigrantes para essas regiões nas últimas décadas, nas duas regiões onde se desenvolve esta pesquisa, o percentual de pessoas nascidas em outro estado permanece alto: $43,6 \%$ no do Jardim Ângela e 34,1\% na Brasilândia, de acordo com o Censo 2010.

${ }^{4}$ Conforme aponta Zaluar (2000), a "ética do provedor", formulada a partir da necessidade de prover o sustento de suas famílias, era o que justificava a dedicação ao trabalho entre as classes populares, não havendo, portanto, uma valorização do trabalho como um fim em si mesmo.
} 
se ouvia muito mais o "barulho de gente" do que o "barulho da cidade", particularmente favorecido pelas "cercas precárias e ruas estreitas" que geravam proximidade entre os moradores (Caldeira, 1984, p. 119-120).

Dessa forma, construía-se um projeto familiar de mobilidade social e um modo de vida mais "comunitário", ao qual somavam-se as CEB, que desempenharam um papel fundamental na articulação e mediação entre a vivência que se tinha nas periferias e os movimentos sociais e políticos que emergiram nesse período. Entre o cotidiano nos bairros periféricos, o passado rural comunitário - tratado de forma nostálgica e muitas vezes idealizado - e os princípios pregados pelas CEB havia diversas afinidades.

Em ambas as regiões onde esta pesquisa foi desenvolvida foram trazidos relatos a respeito da centralidade da Igreja Católica, e principalmente das CEB, para o surgimento dos primeiros movimentos de reivindicação política. A organização das Comunidades de forma horizontal fazia com que elas funcionassem como "espaço de reconhecimento" e confiança entre seus membros, a partir do qual se efetuava "uma reelaboração das experiências cotidianas de existência, com categorias para criticá-las e referências para ações coletivas visando transformá-las" (Sader, 1988, p. 162).

Na região da Brasilândia, o relato mais significativo a respeito da história das CEB foi de Dona Nair ${ }^{5}$ de 81 anos. A solidariedade entre os membros e destes para com a vizinhança era marca constante das CEB. Assim, uma série de atividades que visavam atender de forma emergencial as necessidades da população eram desenvolvidas por Dona Nair e suas companheiras: a distribuição de cestas básicas, a preparação da chamada "multimistura" - uma farinha desenvolvida pela Pastoral da Criança e oferecida como complemento alimen-

5 Com exceção de lideranças publicamente conhecidas, os nomes dos personagens foram trocados com o objetivo de proteger o sigilo e a privacidade dos informantes. 
tar para crianças em condição de subnutrição - a doação de roupas e aquela que era uma das principais marcas das CEB naquele período: as creches comunitárias.

O relato de Nair e de várias outras mulheres ${ }^{6}$ apontam para a ação coletiva como decorrência da identificação de uma necessidade concreta. Foi assim que da carência material e da necessidade das mães que precisavam trabalhar e não tinham onde deixar seus filhos, surgiu, em um primeiro momento, uma solidariedade interna. $\mathrm{O}$ apoio mútuo entre as mães e o auxílio material da igreja, que muitas vezes, como no caso da creche em que Dona Nair trabalhou, cedia o espaço e alguma outra estrutura básica, como o alimento para as crianças, ampliava os laços entre os que atuavam na comunidade e o restante da vizinhança.

Contudo, as atividades das CEB iam muito além do assistencialismo ou da mera discussão de um texto bíblico ou da escuta passiva do evangelho por um padre ou estudioso. A partir das leituras religiosas, eram realizadas atividades de reflexão coletiva. Assim, os presentes faziam uma "releitura das próprias condições de vida à luz de um texto bíblico, onde viam a referência à justiça e aos valores mais profundos da existência" e isso "produzia uma atitude crítica de dimensões insuspeitadas” (Sader, 1988, p. 207). Até hoje, Dona Nair guarda lembranças dos aprendizados desse período quando faz referência à luta dos hebreus contra a escravidão no Egito para afirmar que o povo precisa "erguer a cabeça e reagir".

Desenvolveu-se, assim, um discurso de acordo com o qual o paraíso não era um prêmio, mas sim "algo que se conquista com Deus no coração” (Cardoso, 1982, p. 55). Nesse

\footnotetext{
${ }^{6}$ Diversos homens também participavam de CEB, mas a maioria dos participantes e, principalmente das lideranças, era formada por mulheres, o que trazia uma importante tensão uma vez que "o papel tradicionalmente reservado à mulher na família propiciava seu interesse pela religião, mas não estimulava sua participação política" (Cardoso, 1982, p. 57), assim, questionamentos a respeito da igualdade de gênero também eram comuns nas CEB.
} 
mesmo sentido, ouvi mais de uma vez entre as militantes que participavam de CEB que "fé sem política não funciona".

A partir dessa experiência nas CEB, questões que eram tidas como privadas e até naturais passaram a ser vistas como problemas públicos que eram compartilhados por diversas famílias e que poderiam ser alterados por novas práticas sociais. Como aponta Cefaï (2009, p. 27), a descoberta de "pontos comuns" e a "constituição de uma linguagem comum, na enunciação de repertórios de identidade coletiva e na confecção de modos de engajamento público”, são elementos essenciais para converter disputas privadas e mal-estares pessoais em causas coletivas e, assim, construir um "problema público" ( public issue).

Assim, a partir dessas discussões, além das atividades coletivas que buscavam resolver os problemas da própria comunidade, como as já citadas creches, doações e mutirões para limpeza ou construção de centros comunitários, começaram a surgir ações "para fora", de reivindicação junto aos poderes públicos (Sader, 1988, p. 207). As mulheres participantes de CEB que foram interlocutoras dessa pesquisa lembram com orgulho de suas lutas e conquistas mais diversas, tais como escolas, creches, pontos ou linhas de ônibus, asfaltamento de ruas, postos de saúde e até hospitais.

No Jardim Ângela, as marcas da militância nas comunidades católicas são ainda mais fortes, tanto pela pujança que essas comunidades tiveram no passado - é na região que fica a Paróquia da Vila Remo, onde surgiram os Clubes de Mães da Zona Sul de São Paulo (ver Sader, 1988, p. 199-212) quanto pela continuidade do trabalho iniciado pela Igreja graças à atuação do Padre Jaime, um padre irlandês que chegou no Brasil em 1969 e no Jardim Ângela em 1987.7

\footnotetext{
7 A importância do Padre Jaime para os movimentos sociais da região do Jardim Ângela será melhor explorada na seção seguinte.
} 
Maria de Felipe era uma das mulheres que participavam das CEB do Jardim Ângela desde os anos 1970 e ressalta a importância da Igreja para aqueles movimentos, inclusive como forma de fugir da repressão da ditadura militar que governava o país na época, conforme ela mesma relatou: "[naquele período,] reuniu cinco pessoas na rua já era subversivo" (Informação verbal) ${ }^{8}$ Dessa forma, ela conta como a partir dos clubes de mães surgidos nas CEB foram sendo criadas diversas iniciativas que buscavam melhorias para as condições de vida na região:

Na verdade, assim, a gente vem de movimentos populares e sociais desde a década de 1970. Então, nós criamos vários movimentos, os primeiros foram os grupos de mulheres que eram clubes de mães na época, né? E a partir dos clubes de mães, nós fomos criando diversos movimentos sociais de luta por água, esgoto, asfalto, creche, escola, tudo o que a gente não tinha no bairro, nós começamos a lutar. Essa luta nós começamos lá na Vila Remo. Depois de 1973, eu me casei, mudei pra cá [Jardim Copacabana] e aí nós demos continuidade na nossa luta, né? [Eu] participava das Comunidades Eclesiais de Base. Aí nós fundamos também um atendimento pra crianças e adolescentes, que era voluntário [...]. Como muitas mães queriam participar e não tinham como participar, queriam trabalhar e não tinham como trabalhar por conta das crianças, aí nós nos reunimos e uma parte dessas mães começaram a cuidar voluntariamente das crianças e outras foram trabalhar e participar dos movimentos. Então foi assim que surgiram os grupos de mulheres, de onde surgiram as lutas, de onde surgiram todos os movimentos. Um dos principais movimentos que nós criamos foi

8 Declaração fornecida por Maria de Felipe em entrevista no Jardim Ângela, em São Paulo, em novembro de 2015. 
o movimento contra a carestia, ${ }^{9}$ que teve assim uma repercussão nacional, internacional, teve muita força na época. (Informação verbal) ${ }^{10}$

A narrativa de Maria de Felipe é comum entre várias pessoas com quem conversei a respeito de suas experiências nas CEB e nos movimentos sociais daquele período. Uma ação ia quase que naturalmente se desdobrando em outra. A identificação de uma necessidade coletiva, como as creches, levava à ajuda mútua e, em seguida, à reivindicação e luta para que o Estado garantisse aquele direito.

Essas falas explicitam o papel desempenhado pelas CEB nesse período na construção de laços entre aqueles sujeitos e deles com seu bairro. Ao valorizar o modo de vida local e colaborar para a interpretação das condições em que viviam os trabalhadores pobres das periferias, as CEB desempenharam papel fundamental para a passagem da esfera doméstica para uma esfera pública ampliada, constituindo-se como uma esfera pública subalterna na qual formou-se uma cultura pública (Cefaï, 2009) e uma disposição para a luta pelos direitos dos trabalhadores urbanos que viviam em áreas periféricas. ${ }^{11}$

9 Sobre a história do movimento contra a carestia, também conhecido como Movimento do Custo de Vida e sua relação com os clubes de mães, ver Sader (1988, p. 211-221).

${ }_{10}$ Declaração fornecida por Maria de Felipe em entrevista no Jardim Ângela, em São Paulo, em novembro de 2015.

11 Cumpre salientar que as CEB e o catolicismo progressista advindo da teologia da libertação - que Sader (1988) chama de "matriz discursiva" e que aqui são tratados como "esfera pública subalterna" - são partes de um contexto mais amplo de mobilização das chamadas classes populares, que culminou com uma série de movimentos sociais e políticos de oposição à ditadura militar. Esses movimentos, que incluem o chamado "novo sindicalismo", estão na base de importantes instituições políticas que surgiram nesse período, como a Central Única dos Trabalhadores (CUT) e o PT, e foram fundamentais para a mobilização que se alcançou no processo Constituinte de 1988. No entanto, o foco etnográfico deste artigo conduziu o texto a dar maior ênfase às CEB em detrimento de outros espaços de formação e mobilização do período. 


\section{Da confrontação à negociação: individualismo $\mathrm{e}$ institucionalização dos movimentos sociais na segunda geração de moradores das periferias de São Paulo}

A promulgação da Constituição de 1988, ao mesmo tempo em que pode ser entendida como auge da mobilização das classes populares e do direcionamento de sua atuação para o Estado, marca também o início de um processo de derrocada dessa efervescência política. A vitória de Fernando Collor de Mello nas eleições presidenciais de 1989 e seu programa de cunho neoliberal, continuado ao longo dos governos seguintes, significaram um duro golpe para esses sujeitos.

Na cidade de São Paulo, a eleição de Luiza Erundina do Partido dos Trabalhadores (PT) no pleito municipal de 1988 representou uma importante vitória desses movimentos sociais que se organizaram nas décadas anteriores, mas foi também um importante desafio para a implantação de políticas públicas reivindicadas por eles e para a manutenção da mobilização coletiva diante da nova posição institucional alcançada. Esses desafios tiveram consequências dúbias, como será visto adiante.

Com isso, a década de 1990 e o início dos anos 2000 trouxeram importantes alterações naquele modo de vida periférico, afetando sobretudo a geração que entrava no mercado de trabalho naquele momento.

A primeira mudança relevante pode ser percebida no mundo do trabalho. A prolongada crise econômica, a flexibilização das relações de trabalho e a derrocada do trabalho industrial na cidade de São Paulo desestruturaram "todo o esquema em função do qual as classes populares organiza[va]m sua prática social” nos anos anteriores (Durham, 1988, p. 197). "A sociabilidade centrada no trabalho cessou de existir", o que trouxe como consequência o esvaziamento da esfera pública (Oliveira, 2007, p. 35). A consequência mais imediata dessas mudanças foi a ampliação da busca 
por soluções individuais mesmo para problemas comuns aos moradores das periferias.

No nível dos bairros, dois elementos merecem destaque devido às suas consequências em termos de redução da sociabilidade local. De um lado, o próprio desenvolvimento dessas regiões, com o asfaltamento e ampliação de ruas e o aumento da circulação de carros. De outro, o expressivo aumento da criminalidade violenta que ampliou o medo de roubos, furtos e assaltos. ${ }^{12}$ Assim, as residências autoconstruídas, que antes já funcionavam como consolidação do projeto familiar de ascensão social, passam por um processo de "fortificação" (Cf. Cavalcanti, 2009) por meio da adoção do que Caldeira (2000) denominou de "estética da segurança", isto é, aparatos de vigilância e controle desenvolvidos para garantir segurança e status social para famílias de classes alta e média alta de São Paulo, que podem ser traduzidos em câmeras e cercas eletrônicas, mas também em muros e grades cerradas. Assim, essa estética da segurança tornou-se também signo de distinção (Bourdieu, 2007) nas periferias da cidade.

Ademais, há que se ressaltar uma importante mudança que ocorreu no campo religioso no Brasil e, em especial, na região metropolitana de São Paulo, que enfraqueceu a capacidade de articulação política e social advinda das CEB. Essas mudanças podem ser resumidas em três grandes tendências: a multiplicação das alternativas religiosas; uma maior mobilidade de pessoas entre as distintas religiões e também para fora delas, que passam a se identificar como "sem religião"; e o trânsito de ideias e práticas religiosas, fazendo emergir zonas religiosas "híbridas" como o neopentecostalismo e a Renovação Carismática Católica, que

12 Conforme aponta Zaluar e Leal (1998, p. 209), o aumento da violência nas periferias e favelas do Brasil produziu um crescimento da oposição entre os mundos da casa e da rua, a partir de uma redefinição da rua como "espaço da violência incontrolada". Nesse contexto, a imagem da rua passou a ser associada ao mal e ao perigo, em razão da presença de traficantes, ladrões, assaltantes e acabou por produzir "a maior transformação da vida privada nos últimos vinte anos". 
adotam ritos e conceitos de outras doutrinas como parte do processo de concorrência por fiéis (Almeida, 2004).

Enquanto em 1990 os católicos representavam quase $80 \%$ dos moradores da região metropolitana de São Paulo, em 2000 esse percentual já havia caído para cerca de $67 \%$ e para menos de $57 \%$ em 2010, conforme dados do Censo. ${ }^{13}$ Além disso, o próprio catolicismo progressista já vinha perdendo força dentro da institucionalidade da Igreja, com a retirada de apoio às $\mathrm{CEB}$, a subdivisão da arquidiocese de São Paulo, a multiplicação de paróquias, a nomeação de bispos com perfil mais conservador, a troca de padres e o incentivo à renovação carismática. ${ }^{14}$

Ainda que haja, em parcela expressiva dessas religiões, o incentivo à formação de redes de solidariedade, reciprocidade e de laços de confiança, essas redes tendem a priorizar "irmãos de fé", ou seja, aqueles que comungam da mesma religião. Dessa forma, os evangélicos tendem a participar menos de outros níveis associativos, como partidos, sindicatos, união de moradores e espaços comuns de lazer, uma vez que as igrejas tendem a competir pelo tempo livre dos fiéis por meio da construção de espaços de sociabilidade dentro da própria igreja, como grupos de música, teatro, esportes, sempre ligados à religião (Almeida, 2004). Com isso, parte importante do incentivo à sociabilidade local e à construção de laços mais amplos na vizinhança advindos das comunidades católicas se perdeu nessa transição geracional.

\footnotetext{
${ }^{13}$ De acordo com o survey que foi aplicado por esta pesquisa no primeiro semestre de 2015, no Jardim Ângela, 23,6\% se disseram evangélicos pentecostais, $8 \%$ evangélicos não pentecostais, $55,8 \%$ católicos, $4,5 \%$ disseram seguir outras religiões, e $7 \%$ disseram ser ateus ou não ter nenhuma religião, $1 \%$ não respondeu. Na Brasilândia, 24\% se declararam como evangélicos pentecostais, 5,7\% como evangélicos não pentecostais, 46,9\% como católicos, 14,6\% disseram praticar outra religião e $8,3 \%$ disseram ser ateus ou não ter religião, $0,5 \%$ não respondeu.

14 De acordo com dados de Almeida (2004), entre o começo dos anos 1990 e os anos 2000, os adeptos das práticas "carismáticas" passaram de 3,8\% para 9,3\%, na região metropolitana de São Paulo.
} 
Com isso, o modo de vida comunitário pregado pelas CEB não encontrava mais a mesma reverberação e a mesma afinidade com o modo de vida da população periférica de São Paulo. Além disso, não só o catolicismo perdeu parte de seus fiéis para igrejas neopentecostais, como a própria Igreja Católica promoveu o enfraquecimento das CEB e reduziu a influência da teologia da libertação e de padres progressistas, a partir da divisão da arquidiocese de São Paulo e da nomeação de bispos conservadores para as novas regiões. Assim, as CEB, centro de irradiação e formação dos movimentos sociais de décadas passadas foram progressivamente perdendo sua força e importância política e social.

No âmbito doméstico, a família foi aos poucos deixando de funcionar como "unidade de rendimentos", reduzindo a possibilidade de receber "agregados" e dando mais espaço para que cada membro da família buscasse, na produção e no consumo, agir de acordo com seus desejos e necessidades pessoais.

Diante dessas mudanças no modo de vida nas periferias, alterações significativas também ocorreram no ativismo político e social desses sujeitos. Praticamente não encontrei continuidade institucional de maior fôlego das iniciativas que Dona Nair descrevera como constantes nos anos 1980 na Brasilândia. A CEB que ela frequentava fechou por um período, pois a casa onde funcionava fora ocupada por moradores sem teto. Mesmo reaberta depois de um tempo e ainda funcionando atualmente com missas aos domingos, a assiduidade dos participantes e seu poder de mobilização política é infinitamente menor do que no auge de seu funcionamento há 30 ou 40 anos.

A ausência de uma continuidade institucional deixou para os indivíduos, muitas vezes membros da família de antigos militantes, a incumbência de seguir com as atividades políticas na região. Uma das filhas de Dona Nair, Sandra, de 49 anos, trabalhou durante muitos anos no setor químico e militou no Sindicato dos Químicos de São Paulo. A partir 
dessa militância seguiu os caminhos da mãe e se filiou ao PT e, mais recentemente, exerceu um cargo comissionado na prefeitura, indicada por um vereador com quem mantinha relações políticas. Junto com um de seus irmãos, ela diz que gostaria de desenvolver projetos sociais na região, mas mostra-se frustrada por não conseguir criar uma estrutura que lhe permita estabelecer algo mais permanente para além das festas comunitárias de natal e dia das crianças que promovem anualmente. $\mathrm{O}$ irmão de Sandra trabalha como pedagogo em uma creche conveniada com a prefeitura e desenvolve um projeto social na garagem de casa em que busca incentivar a leitura entre crianças por meio da "contação de histórias".

No Jardim Ângela, a história é um pouco diferente, tanto devido à força da mobilização anterior, como citado no caso dos Clubes de Mães da Zona Sul - de onde surgiram instituições do terceiro setor como a Sociedade Amiga Esportiva do Jardim Copacabana (Saec) fundada por Maria de Felipe - quanto pelo apoio que a paróquia local seguiu dando a esses movimentos. Mesmo com a nomeação de um Bispo conservador para a região, Padre Jaime conseguiu manter certa autonomia de ação graças ao apoio da ordem de São Patrício, na Irlanda, da qual é membro desde antes de se mudar para o Brasil.

No discurso do Padre Jaime, de Maria de Felipe e no de muitos outros militantes com quem conversei sobre as mudanças nos movimentos sociais dos anos 1980 para os 1990, os convênios com o poder público aparecem quase como consequência lógica da militância anterior que desenvolviam nas CEB, além de serem formulados como resposta da sociedade ao avanço do "mundo do crime". ${ }^{15}$

Dessa forma, a solidariedade das mães nas creches e a reivindicação de políticas e equipamentos públicos levou à

\footnotetext{
15 Sobre o processo de "expansão do mundo do crime" nas décadas de 1990 e 2000 ver Feltran (2011).
} 
necessidade de criação de instrumentos para manter aqueles equipamentos e serviços funcionando. Assim, os convênios surgiram como instrumento para que Estado e sociedade civil pudessem gerir os serviços públicos em parceria. Desse modo, em 1989, a Saec, fundada em 1982, assinou seu primeiro convênio com a prefeitura, dando origem ao seu primeiro Centro para Crianças e Adolescentes (CCA), que funciona até hoje no Jardim Copacabana, bairro do distrito do Jardim Ângela, atendendo crianças e adolescentes até os 14 anos de idade.

Nos anos seguintes, a Saec estabeleceu diversos outros convênios com o poder público municipal e foi progressivamente ampliando seus serviços sociais. Atualmente, além do CCA, ela também é responsável por um Centro de Juventude (CJ), que atende jovens de 14 a 17 anos, um projeto de alfabetização de jovens e adultos e um Núcleo de Convivência para o Idoso (NCI), todos no Jardim Copacabana. Entre 2009 e 2014, a Saec viveu uma grande ampliação, passando de três convênios com a prefeitura para vinte e dois e atualmente presta serviços em diversas regiões da cidade de São Paulo.

No caso da Paróquia Santos Mártires, na qual o Padre Jaime é o pároco ao lado do Padre Eduardo, a história é semelhante. A partir da creche voluntária que funcionava no salão da igreja desde 1989, percebeu-se que seria necessário não apenas creches, mas também espaços para as crianças na faixa de 5 a 6 anos onde elas pudessem ficar no contraturno escolar, já que ainda eram muito pequenas para ficar sozinhas enquanto as mães trabalhavam. Assim, entre 1991 e 1992, eles firmaram os primeiros convênios para que a prefeitura repassasse os recursos para a manutenção desses serviços por meio da Sociedade Santos Mártires, uma Organização Não Governamental (ONG) ligada à Igreja, mas com relativa autonomia para gerir os serviços conveniados. 
Ao longo dos anos 1990 e 2000, a Santos Mártires foi progressivamente ampliando sua atuação, mas, ao contrário da Saec, procurou manter-se restrita à região do Jardim Ângela. Atualmente, eles coordenam mais três CCA, cinco creches, um projeto de alfabetização de jovens e adultos, além de outros serviços como a Casa de Sofia, voltada para atendimento a mulheres vítimas de violência doméstica, um serviço de acompanhamento de adolescentes em medidas socioeducativas, um serviço de acolhimento para crianças e adolescentes em situação de risco, um projeto de reciclagem de resíduos, entre outros.

Apesar desse caminho da transformação de associações reivindicativas em organizações sociais gestoras de serviços públicos ser narrado muitas vezes como natural, é nítida a mudança de uma postura mais combativa e reivindicativa que esses sujeitos adotavam até os anos de 1980 - no sentido de exigir melhorias de seus bairros e demandar serviços públicos até então inexistentes - para uma atitude de colaboração e cooperação com o Estado que passa a ser a regra a partir da década de 1990.

Naquele momento, o projeto de ampliação da democracia e dos direitos sociais, que parecia conquistar espaços crescentes com a Constituição de 1988 e com a vitória de uma candidatura progressista na capital paulista nesse mesmo ano, encontrou-se com um projeto de Estado em nível nacional que buscava se isentar progressivamente de seu papel de garantidor de direitos, por meio do encolhimento de suas responsabilidades sociais, transferindo-as para a sociedade civil. Ocorre, então, o que Dagnino (2004, p. 141) chama de "confluência perversa", entre esses projetos, uma vez que, mesmo apontando para direções opostas, ambos "requerem uma sociedade civil ativa e propositiva".

É preciso apontar, todavia, que o trabalho em ONG e a gestão de serviços públicos por meio de convênios não são as únicas formas de militância desenvolvidas por esta geração. 
Com o processo de consolidação da democracia e a abertura de espaços de participação popular, os movimentos sociais das periferias ocuparam boa parte desses espaços. Assim, é possível acompanhar diversos militantes que participam de forma ativa em audiências públicas, conselhos gestores de equipamentos públicos, como praças, parques e postos de saúde, conselhos consultivos no âmbito das subprefeituras regionais ou em conferências temáticas. Além disso, é bastante comum que os militantes se vinculem a campanhas ou mandatos de vereadores da cidade, em geral ligados ao PT.

Finalmente, é preciso ponderar que há um mecanismo de atuação que em alguma medida foge a essa regra de repertórios mais negociais de ação. Trata-se da ação civil-pública, em geral feita em parceria com a Defensoria Pública e com o Ministério Público, e funciona como último recurso que algumas organizações tendem a utilizar quando a negociação com o poder público não rende os frutos esperados. De todo modo, trata-se ainda de um mecanismo que segue no âmbito institucional com a diferença que faz uso da esfera jurídica e não política.

O nível de conhecimento de mecanismos políticos, jurídicos e institucionais que esses militantes desenvolveram é bastante elevado. Por outro lado, a necessidade desse conhecimento e de disposição para atuar em diferentes frentes acaba sendo, muitas vezes, um mecanismo de desestímulo para que outras pessoas sejam integradas ao processo de luta política. É preciso conhecer os mecanismos de gestão e prestação de contas para fazer um convênio, é preciso ter prática na oratória pública e na negociação para ter uma atuação efetiva em um conselho ou conferência, é preciso saber como funciona um processo jurídico e contar com apoio de advogados e promotores para entrar com uma ação civil-pública.

Em suma, o papel de formação de sujeitos políticos e de construção de questões públicas desempenhado pelas CEB foi 
dando lugar para a herança de engajamento familiar e, principalmente, para os espaços institucionais criados a partir dos projetos sociais e da atuação política desses militantes. Esses espaços desempenham, portanto, um papel relevante no fomento de uma cultura política democrática e participativa e funcionam como espaços de educação não-formal (Gohn, 2011) para essa segunda geração de moradores das periferias urbanas.

As práticas de sociabilidade e deliberativas que se estabelecem nesses espaços, contudo, são significativamente menos densas do que as que ocorriam nas CEB. Além disso, esses repertórios de ação têm um caráter muito menos contestatório e mais negocial do que aqueles utilizados na geração anterior. Desse modo, o foco prioritário dessas instituições que formaram politicamente a segunda geração não está tanto na constituição de uma infrapolítica do subalternos (Scott, 1990), no sentido de construir as bases sobre as quais a ação política pode ocorrer, mas principalmente de conquistar espaços dentro da esfera pública constituída pelo próprio Estado a partir dos quais se possa influenciar o rumo de políticas públicas específicas.

Assim, enquanto os processos de mobilização social levados a cabo nos anos 1970 e 1980 pelos movimentos sociais alargaram a noção de política e politizaram o cotidiano dos moradores, nos anos 1990 e 2000 parece ocorrer justamente o contrário. O político se reduziu ao posicionamento eleitoral para a maioria das pessoas e a participação mais efetiva acabou cada vez mais restrita aos "iniciados" no processo político. Além disso, essa "profissionalização da militância" acabou por gerar uma dependência em relação ao Estado, seja para a manutenção das entidades e dos serviços ofertados que vivem basicamente de convênios celebrados com o poder público municipal, seja para a manutenção dos próprios militantes que trabalham para entidades sociais ou mais diretamente em cargos de confiança no Estado. A margem de 
manobra desses sujeitos em suas reivindicações acaba reduzida a ganhos marginais, como muitos deles reconhecem. ${ }^{16}$

No discurso dos militantes e ativistas políticos e sociais, tanto da primeira quanto segunda geração até aqui analisadas, há um claro viés de continuidade, quase naturalizado, entre as formas de luta e as práticas políticas que esses sujeitos desenvolveram. Nessa leitura, o próprio processo de democratização política e ampliação da oferta de serviços públicos e de espaços institucionais de participação popular demandavam formas de atuação mais negociais e colaborativas em detrimento de táticas de enfrentamento com o poder público.

Dessa forma, se a institucionalização dos movimentos sociais que se formaram nos anos 1970 e 1980 permitiu uma continuidade mais consistente da atuação política advinda da geração anterior, ela também reduziu a margem de manobra dos sujeitos, uma vez que os tornou dependentes de recursos do Estado - ou ainda de políticos individualmente - e não lhes conferiu acesso a espaços decisórios centrais. Daquele período, os militantes trouxeram consigo a visão da cidadania centrada na efetivação de direitos sociais e na ampliação da democracia política com mais canais de participação. Contudo, as novas formas de atuação política transformaram aqueles militantes aguerridos de outrora em "uma espécie de 'burocracia de base' das políticas sociais" (Feltran, 2011, p. 61). Atualmente, mesmo que em alguns casos ainda procurem organizar e publicizar demandas com abaixo-assinados, pequenas manifestações ou até mesmo entrando com ações civis-públicas, é mais comum que a atuação política dessa geração aconteça por meio da implementação dessas demandas por meio de convênios,

16 Praticamente todos os militantes com que conversei apontam as melhorias em termos de serviços públicos em suas regiões graças a suas lutas históricas e mesmo aos processos de negociação e pressão institucional que desenvolveram nas últimas décadas. Contudo, muitos deles reconhecem os limites da sua atuação e mostram-se preocupados em encontrar outras formas de pressionar o poder público para além da atuação institucional. 
programas e projetos em parceria com o poder público. Os repertórios de ação, por excelência, deixam de ser combativos e de pressão pública para serem negociais e cooperativos. Por consequência, a formação de sujeitos políticos e a colocação em cena de questões públicas passou a ocorrer muito mais em canais institucionais oficiais que, em alguma medida, fazem parte da esfera pública tradicional, ainda que ocupem espaço marginais dessa esfera pública.

\section{De volta ao enfrentamento: crítica ao individualismo e novas possibilidade de ativismo social na terceira geração}

Ao longo dos anos 2000 e 2010, as pressões por individuação entre os moradores das periferias urbanas seguiram fortes. Reforçaram-se e exacerbaram-se por vias diversas os elementos já apontados anteriormente relacionados à "expansão do mundo do crime", aos incentivos ao empreendedorismo como forma de inserção no mundo do trabalho e o contínuo aumento de tendências religiosas baseadas na chamada "teologia da prosperidade". Ainda que esses discursos estivessem presentes pelo menos desde o início da década de 1990, a diferença para esta nova geração está no fato de o sucesso econômico experimentado por muitos, sobretudo a partir de meados dos anos 2000, funcionar como uma base material mais sólida no sentido de conquistar adesão e convencimento do moradores das periferias.

Com relação ao discurso em torno do empreendedorismo, Silva (2002) aponta que a categoria crítica da informalidade, que se opunha ao trabalho formal até início dos anos 1990, foi sendo substituída pelo par empregabilidade/ empreendedorismo no debate público e acadêmico. $\mathrm{O}$ foco dessa nova narrativa buscava colocar a responsabilidade da inserção econômica nos trabalhadores e em suas condições individuais de inclusão no mercado de trabalho, reduzindo a relevância de elementos como as taxas de desemprego ou a baixa oferta de postos de trabalho de qualidade. Assim, 
qualificar-se para ser empregável ou apostar no trabalho autônomo - o empreendedorismo - seja como fonte de renda principal seja como complementação da renda insuficiente, foram se tornando um imperativo da realidade dos trabalhadores das periferias urbanas.

A mensagem que passou a chegar a esses sujeitos, e que progressivamente foi sendo assimilada como única alternativa possível, é a de que deveriam comportar-se como empresários de si mesmos, seja investindo em sua formação técnica e educacional - o chamado "capital humano" -, seja enquanto atitude profissional empreendedora e arrojada. Essa mensagem, com uma forte dimensão simbólico-ideológica interferiu diretamente na autoimagem e visão de mundo dos trabalhadores urbanos (Machado da Silva, 2002). O sucesso econômico de si e o fracasso do outro passou a ser, quase sempre, atribuído ao esforço ou mérito próprio.

No que se refere ao discurso religioso, Antonio e Lahuerta (2014) apontam que o discurso e a práxis do neopentecostalismo funcionam "como um matiz do crescente individualismo cultural do mundo contemporâneo". Esse individualismo apresenta, por um lado, um anseio pela prosperidade material e, por outro, um autoenclausuramento com relação a problemas externos, acarretando uma recusa ao envolvimento com a coletividade.

Ao longo dos anos 1980 e 1990, a teologia da prosperidade dialogou fortemente com a situação de informalidade e de precariedade no mundo do trabalho e com a ideia de empreender, de se virar, de ser patrão de si mesmo. Complementarmente, nos anos 2000, a partir do aumento das possibilidades de consumo, ela passa a apontar para o consumo e a posse de bens materiais como algo positivo e desejável (Fachin, 2019).

Nesse contexto, as interpretações predominantes nas ciências sociais brasileiras que analisam esse período de forma mais estrutural apontam para o esvaziamento da ação política entre 
os mais pobres ou entre as classes trabalhadoras de maneira geral. É o caso de Oliveira (2010), que desenvolveu o conceito de "hegemonia às avessas" com objetivo de pontuar que, sobretudo durante os governos Lula, a despeito de as "classes trabalhadoras" deterem o controle sobre o Estado, elas seguiam mantendo privilégios e interesses de uma elite financeira e rentista. Dessa forma, as políticas sociais, sobretudo as políticas de transferência de renda como o bolsa família, teriam instrumentalizado a questão da pobreza e garantido a adesão de um amplo setor de pobres e miseráveis aos governos petistas, produzindo uma grande despolitização da luta de classes no Brasil.

Singer (2012), por sua vez, argumenta que o "lulismo" teria se apoiado nesse setor social historicamente marginalizado - que ele denomina de "subproletariado" - para promover um jogo de concessões calculado, hora pendendo para o lado do que o autor chama "coalizão rentista" - formada pelos setores financeiros, pelas classes médias e pelo agronegócio -, hora para o lado da "coalização produtivista" - formada pelo empresariado industrial e por trabalhadores formalizados. Com isso, Lula teria desenvolvido um "reformismo fraco", por meio do qual mantinha um "pacto conservador" com as tradicionais oligarquias e elites econômicas do país, mas garantia alguns avanços sociais aos setores mais pauperizados da sociedade brasileira.

Singer traz importantes dados no que se refere ao comportamento eleitoral do grupo que ele denomina "subproletariado", mas faltam elementos concretos que lhe permitam defender a existência dessas duas "coalizões", a "rentista" e a "produtivista", assim como para a existência desse bonapartismo implícito no "lulismo" que pressupõe a ausência de uma hegemonia na sociedade brasileira e, por isso, a possibilidade de Lula "jogar" com os diferentes grupos ou "coalizões". $\mathrm{O}$ autor baseia suas análises unicamente em pesquisas eleitorais, não apresentando maiores dados que lhe permitam identificar quais elementos são relevantes para as mudanças nas 
preferências políticas desses sujeitos. Assim a "virada lulista" do "subproletariado" é atribuída aos benefícios materiais que este grupo obteve, a uma identificação simbólica e pessoal com Lula e a um vago "conservadorismo popular”. São hipóteses que não deixam de ser interessantes, mas que carecem de investigações adicionais para serem comprovadas.

Retornando ao plano etnográfico e à realidade das periferias de São Paulo, é possível observar que o aumento das oportunidades educacionais, aliado à maior oferta de trabalho formal e à ampliação do crédito e dos salários, fez com que as periferias de São Paulo fossem palco de um importante processo de mobilidade social ascendente, sobretudo em termos de renda, o que ampliou significativamente a heterogeneidade social dessas regiões. ${ }^{17}$

Com isso, a busca por signos de distinção social entre vizinhos e de pretensão a um estilo de vida mais próximo às camadas médias da sociedade paulistana é cada vez mais comum. A casa, como já citado, é o elemento mais visível dessa dinâmica. Contudo, a busca pela distinção social se expressa em diversas dimensões que vão dos gostos culturais às orientações políticas, passando pelas opções de lazer e pela visão negativa que parte desses sujeitos adota a respeito da periferia e dos vizinhos que os cercam. Assim, o traço mais marcante dessa dinâmica encontra-se na aspiração pela mobilidade geográfica que tem como fim se livrar do estigma territoria ${ }^{18}$ a que estão submetidos.

$\mathrm{O}$ que pretende-se explorar nas linhas que seguem, contudo, são as potencialidades políticas que as camadas populares que ascenderam economicamente nas últimas décadas podem representar como ator socialmente ativo e

\footnotetext{
17 Para uma leitura mais detalhada do processo de mobilidade social no Brasil e nas periferias de São Paulo na década de 2000, ver Fontes (2018c).

18 Conforme assinala Wacquant (2007), o estigma territorial, ao contrário de outros selos de desonra, pode ser facilmente dissimulado e atenuado, ou mesmo anulado, pela mobilidade geográfica. Para uma análise da disputa simbólica que emerge nas periferias de São Paulo a partir da estigmatização territorial de seus moradores, ver Fontes (2018b), em especial os capítulos 9 e 10.
} 
não apenas como um setor "manipulável”, facilmente "cooptado" ou que estaria satisfeito com sua "integração pelo consumo" oferecida pelos ganhos materiais desse período.

Nesse sentido, notei, ao longo da pesquisa de campo, que, em oposição ao desejo de mobilidade territorial e de negar as "raízes periféricas" - típicos do desejo de distinção social advindo do aumento do individualismo e das possibilidade de mobilidade social mencionados anteriormente - emergiu uma crítica, no sentido de Boltanski (2016), e que pode ser resumida na categoria nativa "espírito da Freguesia". Produzida pelos moradores da Brasilândia, essa categoria faz referência ao desejo de se mudar para o bairro da Freguesia do Ó, um bairro vizinho, mas com padrão de classe média, mais próximo do centro expandido de São Paulo e sem o mesmo estigma de ser periférico. Nas palavras de um dos meus interlocutores, o "espírito da Freguesia” se oporia a um "espírito de comunidade" que ele identifica como predominante em outros tempos e faz referência àqueles que "moram aqui, mas têm espírito de quem não mora aqui" ou, em outros termos, seriam pessoas que pensam: "eu tô na favela, mas eu quero me afastar dela".

Como aponta Telles (2006, p. 182), as novas gerações de moradores das periferias deixam de valorizar aquilo que era mais comum entre seus pais, "essa espécie de 'mundo à mão' que a favela lhes oferece - a família que está por perto, os empregos ali do lado". Os jovens e adultos que habitam essas regiões a partir dos anos 1990 desenvolvem outra relação com a cidade e veem as periferias de São Paulo como um lugar onde "tudo é longe", "não tem nada”, "os lugares são perigosos" e "tudo [é] muito feio".

Dessa forma, apesar das inegáveis melhorias materiais que os moradores dessas regiões vivenciaram nas últimas décadas, estas melhorias foram experienciadas por muitos como um processo de desestruturação de um modo de vida valorizado por eles e que busca ser retomado no presente em formulações tanto a respeito do espaço em que vivem quanto 
na produção cultural local. Essa experiência de desestruturação do antigo modo de vida, marcado pelo "espírito de comunidade" pode ser interpretado como uma situação ${\text { crítica }{ }^{19}}^{19}$

Ademais, outros elementos que compõem o modo de vida dessas pessoas, como a violência e a repressão policial a que estão cotidianamente expostas, a carência de infraestrutura e de serviços públicos de qualidade, a ausência de empregos de qualidade ou a falta de acesso a alguns bens que vão além dos bens de consumo mais populares, como celular, televisão e outros eletrodomésticos, são frequentemente apontados por boa parte dessa pessoas como prova de que suas vidas não melhoraram como poderia parecer ao olharmos apenas para indicadores do seu padrão de vida, como renda e capacidade de consumo. ${ }^{20}$

Diante do enfraquecimento do potencial crítico dos movimentos sociais que tinham emergido nas décadas anteriores, o principal espaço de formação política desenvolvido pelas novas gerações passou a ser os coletivos artísticos e culturais. Como bem aponta D'Andrea (2013, p. 16), "estes coletivos exaltam o orgulho periférico do mesmo modo que são fenômenos decorrentes desse orgulho”.

\footnotetext{
19 De forma resumida, segundo Cefaï (2017), uma situação torna-se problemática quando as reações habituais a um determinado ambiente já não proporcionam a satisfação de suas necessidades e desejos, demandando, portanto, novas práticas e ações com o objetivo ou de se adequar à nova estrutura social ou de modificá-la. Por sua vez, Boltanski e Thevenot (1999) usam a expressão momento crítico para enfatizar tanto a atividade crítica posta em operação pelos sujeitos quanto pelo caráter não usual da situação enfrentada. Entendo que ambos os termos fazem referência a uma questão semelhante e que cada um tem vantagens em termos conceituais. Por um lado, a ideia de um momento crítico aponta com mais precisão tanto para as transformações da configuração social em que os sujeitos estão inseridos quanto para a resposta crítica construída por esses sujeitos. Por outro, a ideia de momento sugere algo mais pontual do que a ideia de situação, assim, momento crítico pode ser confundido como um momento de epifania ou um momento de crise aguda, mas passageira. Situação, por seu turno, que deixa claro que embora se trate de algo conjuntural, ela não será modificada se não por meio da ação social ativa. Dessa forma, combinarei o que as duas expressões têm de melhor e utilizarei o termo situação crítica para definir a especificidade da conjuntura acima resumida. 20 Sobre as possíveis contradições entre o "padrão de vida" e o "modo de vida" das classes trabalhadores, ver Thompson (1966), em especial o capítulo VI.
} 
Fundamentalmente pelo refluxo dos movimentos sociais e pelo avanço do neoliberalismo, o fazer político passa por um momento de crise nas grandes cidades naqueles 1990. Uma das implicações desse refluxo foi o crescimento de coletivos de produção artística nos bairros populares que, na falta de um referencial oriundo de partidos políticos e de movimentos sociais, passaram a se agrupar ao redor de núcleos centrados na produção artística como forma de sociabilidade. Nessa dinâmica histórica, o movimento artístico foi um dos que melhor catalisou as impossibilidades da política, passando a fazer política por meio da atividade artística, consolidando periferia como um modo compartilhado de estar no mundo, um posicionamento político e um discurso ressemantizador sobre o que venha a ser periferia. (D’Andrea, 2013, p. 45)

Nesse sentido, o movimento hip-hop desempenhou papel crucial e teve no grupo Racionais MC's sua maior 80 expressão. Oriundos do Capão Redondo, bairro vizinho ao Jardim Ângela, “os Racionais posicionam-se na periferia, identificam-se como pobres e negros, expressam um explícito antagonismo racial e de classe, e criam um estilo de confrontamento que deixa pouco espaço para a tolerância e para a negociação" (Caldeira, 2011, p. 303).

Os problemas sociais como a violência policial, a violência do "mundo do crime", o desemprego, a segregação residencial, a ausência de infraestrutura urbana, de espaços de lazer, e a ausência de reconhecimento social constituem uma experiência comum entre os jovens periféricos que passam, então, a compartilhar os elementos culturais associados ao hip-hop, fortalecendo "uma ideia de pertencimento e identidade". A periferia passa, progressivamente, de signo de estigmatização a elemento identitário, constituindo-se como um "espaço social e geográfico que gera um denominador comum para jovens negros, mestiços, nordestinos e brancos: a classe pobre" (Macedo, 2014, p. 9). 
Contudo, a mensagem do movimento hip-hop, de importância fundamental para ampliar a autoestima dos moradores das periferias e dar a eles um sentido de unidade, contém um caráter eminentemente negativo, de denúncia, e com pouco espaço para a construção de alternativas políticas. Enquanto os movimentos sociais dos anos 1970 e 1980 contrapunham a visão negativa da periferia com uma imagem positiva de si mesmos como "membros de uma comunidade unida, 'solidária', de famílias trabalhadoras" e articulavam suas necessidades por meio de uma postura de inclusão, reivindicando pertencimento e acesso a serviços públicos e direitos iguais, os membros do hip-hop preocupam-se majoritariamente em denunciar a violência, sobretudo por parte do Estado, e reivindicar uma postura de autoenclausuramento, que rejeita noções de justiça, direitos e pertencimento tal como posto pelo Estado, e que são rearticulados como parte de sua ética (Caldeira, 2011, p. 316-319).

Assim, a construção de uma ideia ressignificada de comunidade encontra seus limites no rap, limites que os movimentos culturais mais recentes têm buscado superar. Conforme muitos jovens relatam, nos últimos anos, os saraus de poesia, por meio da chamada "literatura marginal", têm se tornado a experiência mais marcante em sua formação pessoal e coletiva. A disseminação desse formato por vários bairros periféricos e seu caráter democrático, que permite que o protagonismo do evento seja dividido entre todos que se apresentam, são centrais. Com isso, os saraus têm sido capazes de modificar a forma como esses jovens enxergam a própria realidade, tornando-os mais críticos, mas também mostrando o lado positivo de viver na periferia.

Karina, 36 anos, moradora do Jardim Ângela e filha de pais que foram militantes de movimentos sociais nos anos 1980 resume bem o sentimento dos que frequentam os saraus de poesia: 
É meio aquele lance de as pessoas saírem de casa pra ter contato com outras, que, na minha geração, a gente fazia isso na Igreja. E essa geração tem um espaço que é muito mais bacana que são os saraus. Então, o sarau acolhe a molecada do rap, que com música e rima eles conseguem refletir sobre questões políticas que são fundamentais. Tem aquele lance da poesia, que é isso de você sair dessa coisa concreta, em que ao mesmo tempo que você faz aquela movimentação com as palavras você tá fazendo isso com seu olhar, que eu acho que também ajuda muito. E tem o fato de as pessoas poderem estar em contato em um lugar que é alegre, sabe? Desenvolver vínculo mesmo, porque eu acho que você só começa a se importar com o meio quando você desenvolve vínculo com as pessoas e com o lugar. É aquela noção de pertencimento, né? Acho que os saraus fazem isso de uma forma muito bacana. (Informação verbal) ${ }^{21}$

Desse modo, os saraus são interpretados por seus próprios frequentadores como espaços de formação política e cultural, bem como para a criação de vínculos afetivos entre as pessoas e delas com o local onde vivem, exercendo papel semelhante ao que as CEB desempenharam no passado, como uma esfera pública subalterna onde uma infrapolitica pode se desenvolver. Além disso, como Karina ressalta, a poesia é capaz de mudar a forma como as pessoas enxergam a própria realidade, refletindo sobre questões políticas a partir da realidade concreta dessas pessoas. Finalmente, ela destaca que essa criação de vínculos poderia levar as pessoas a se importar mais com a própria região, ao ampliar a sensação de pertencimento àquela realidade social.

Os saraus, portanto, se apropriam da mensagem produzida pelo hip-hop, que, ao mesmo tempo em que denunciava

${ }^{21}$ Declaração fornecida por Karina, de 36 anos, em entrevista no Jardim Ângela, em São Paulo, em fevereiro de 2016. 
criticamente as mazelas das periferias, valorizava seu modo de vida e moradores daquelas regiões. Contudo, os saraus fazem isso trazendo a música, a arte e a poesia para um espaço horizontal e democrático em que qualquer um pode ser protagonista, trazer sua mensagem e produzir sua própria leitura do mundo, como aponta a poeta Mariana Felix:

Pra mim o Sarau e o Slam é [sic.] quase uma religião, é a religião a qual pratico, porque nós somos todos DEUSES de nós mesmos. [...] Escritora eu já era, mas eu não era a pessoa que eu sou hoje e o Sarau e o Slam me proporcionaram várias desconstruções e reconstruções. Várias coisas que eu acreditei uma vida inteira, eu derrubei tudo e comecei a construir tudo de novo, ouvindo experiências de outras pessoas, aprendendo com outras pessoas. O Slam e o Sarau é [sic.] um espaço que o escritor tem a influência sobre essas pessoas e ele pode ser influenciado. É o momento que todos nós somos "deuses". (Mariana Felix apud Silva, 2017, p. 97)

Essa democratização do espaço permite a entrada em cena de outros temas que eram desprezados pelo rap e torna o sarau um espaço de reconhecimento para esses jovens. Assim, temas como o feminismo e a homofobia ganham destaque ao lado de temas já tradicionalmente tratados, como a desigualdade, a violência e o racismo. ${ }^{22}$

\footnotetext{
${ }^{22}$ Isso não significa que os saraus sejam espaços livres de contradições e que não reproduzam em diversos momentos dinâmicas opressoras como o machismo e a homofobia, como depoimentos que ouvi sobre o favorecimento de determinados poetas no momento da declamação e o excesso de vaidade de alguns poetas. Sobre o machismo no interior do circuito cultural das periferias ver a interessante análise de Medeiros (2017) a respeito da campanha \#nãopoetizeomachismo. Do mesmo modo, é importante ressaltar que, ao mesmo tempo em que os saraus são espaços de afirmação coletiva do direito de fazer arte, sair da invisibilidade e da criminalização, eles também funcionam como espaço de conquista de prestígio social e de ganhos econômicos individuais por meio da promoção de eventos ou venda de livros. Em outras palavras, "a transformação social virou também projeção e afirmação pessoal” (Tommasi, 2013, p. 28).
} 
É desses movimentos culturais que se consolidam nos anos 2000 e se expandem por diversas periferias de São Paulo que se forma uma cultura periférica: um conjunto de produções simbólicas "por meio do qual se organizam formas de sociabilidade, modos de sentir e pensar o mundo, valores, identidades, práticas sociais, comportamentos coletivos, etc. [sic.]; e que caracteriza o estilo de vida dos membros das classes populares que habitam em bairros periféricos" (Nascimento, 2010, p. 119). Periféricos, ou "guerreiros", como às vezes se denominam, formam uma identidade coletiva que busca valorizar a luta coletiva pela melhoria de vida em oposição à simples luta individual representada pelo espirito da Freguesia. A formação da cultura periférica é, portanto, o ponto inicial para a formação do que D'Andrea (2013) chama de "sujeito periférico", isto é, aquele que se reconhece como periférico, se orgulha de ser da periferia e age politicamente a partir dessa condição social.

A categorização dessa manifestação como cultura periférica, seguindo Nascimento (2010), não ocorre porque ela é capaz de representar toda a diversidade cultural das cada vez mais heterogêneas periferias de São Paulo. Tampouco significa que ela seja mais "verdadeira" ou "autêntica" do que outras manifestações culturais das periferias urbanas. A alcunha se deve ao fato de ela se reivindicar como tal, isto é, como sendo representante de um modo de vida próprio da periferia, o que abarca comportamentos, valores, práticas, linguajares, modos de se vestir, visões de mundo. A partir disso, ela se coloca em luta com a "cultura dominante" e contra a desestruturação do antigo modo de vida afetado pela violência e pelo individualismo e pela busca por distinção advinda do aumento do individualismo e das possibilidades de ascensão social.

Compreende-se, então, a cultura periférica de forma semelhante à que Hall (1981) compreende a "cultura popular", isto é, sem a preocupação de encontrar seu "sentido puro", uma vez que se trata, na realidade, do "terreno sobre 
o qual as transformações são operadas”. É necessário, portanto, compreender a conformação dessa cultura dentro da "dialética da luta cultural", na qual o foco está na "relação entre cultura e as questões de hegemonia" (Hall, 1981).

Contudo, falta ainda analisar como essa crítica ao espírito da Freguesia e o processo de construção de uma cultura periférica poderiam dar espaço à emergência de movimentos sociais contemporaneamente. Afinal, os diversos coletivos culturais que têm se espalhado pelas periferias paulistanas recentemente e que organizam saraus e outras atividades artísticas e culturais são dotados de características bastante peculiares que os diferenciam dos tradicionais movimentos sociais. Seu caráter muito menos institucionalizado e sem pautas concretas como a demanda por um serviço social específico são, ao mesmo tempo, sua força e sua fraqueza. Assim, a atuação política, entendida em sentido estrito de pressionar o poder público na direção de determinadas demandas não está na agenda desses movimentos. ${ }^{23}$

De todo modo, os saraus de poesia e demais atividades políticas e culturais que têm tido lugar nas periferias urbanas desempenharam um papel crucial na construção e no espalhamento de um discurso em torno dos direitos entre os moradores das periferias de São Paulo, em especial entre os mais jovens. Conforme apontam Novaes e Alvim (2014, p. 296), "a noção de "direitos" evoca o poder público e, consequentemente, leva à cobrança por políticas públicas”. Com isso, a relação com o Estado torna-se inescapável.

Ademais, a mensagem de empoderamento individual e coletivo, horizontalidade e valorização das singularidades nas formas de organização e, sobretudo, a construção de uma visão

${ }^{23}$ Em casos pontuais, esses coletivos chegaram a estabelecer uma relação de diálogo com o Estado, como no processo de aprovação da chamada Lei de Fomento das Periferias, em 2016, ou em eventuais editais a que concorreram junto à Secretaria Municipal de Cultura. Contudo, trata-se de uma relação voltada para processos-meio, isto é, que buscam assegurar recursos para própria manutenção de suas atividades e não para objetivos finalísticos de efetivação de direitos sociais. 
positiva sobre ser periférico construíram uma cultura pública comum e uma "disposição de luta” (Cf. Januário et al., 2016) que permitiram um "transbordamento societário" (Cf. Bringel e Pleyer, 2015) de mobilizações sociais que foram iniciadas externamente às periferias, mas que tiveram importantes reverberações e adesões nas periferias de São Paulo. Refiro-me, principalmente às mobilizações de junho de 2013, mas também às ocupações de escolas públicas do fim de 2015.

Como apontam Pinheiro-Machado e Scalco (2018), "além das ocupações em si, o Brasil pós-2013 se caracteriza pela multiplicação de coletivos negros, LGBTs [sic] e feministas, marcados pela lógica autonomista da descentralização e horizontalidade". Dessa forma, se é verdade que "a narrativa político-partidária, ou mesmo movimentista” é desinteressante para os jovens que vivem nas periferias paulistanas (Feltran, 2011, p. 261) e que nenhum dos atores políticos constituídos atualmente é capaz de traduzir e representar os anseios e aspirações desses jovens, isso não significa que eles tenham relegado as lutas por direitos a um segundo plano. O que é possível observar, na realidade, é um processo de ressignificação das formas e conteúdos dessas lutas a partir da própria experiência desses sujeitos.

Voltemos ao plano etnográfico para analisar como esses elementos se cruzam nas trajetórias de jovens dessa nova geração. Mari, 17 anos, moradora da Brasilândia, representa bem essa visão de mundo disseminada entre muitos jovens das periferias de São Paulo que se engajaram em coletivos culturais e em mobilizações políticas. Desiludida com a política institucional e partidária, sobretudo pelo que enxerga como limitações dos governos progressistas sob os quais ela passou boa parte de sua vida, ela se diz adepta do "Fora todos", mas é ciente que essa é uma proposta limitada, pois não apresenta alternativas em termos de organização política.

Mari é neta de Dona Nair, pioneira das CEB na região, que apresentei na terceira seção deste texto e filha de Sandra, 
militante do PT e que trabalhava em um cargo comissionado na prefeitura, mencionada na quarta seção. Apesar de ter convivido desde pequena com a política e de debater com a mãe diversas questões sociais, ela não tem dúvidas em afirmar que os saraus de poesia, em especial o Sarau da Brasa, que ocorre um sábado por mês na região, foram fundamentais para tirá-la, assim como vários de seus amigos, do que ela mesma chama de "zona de conforto", "aquela coisa de... vou trabalhar e fazer faculdade”. Graças ao sarau, ela diz ter começado a "olhar para o lado" e perceber "que precisava mais disso na quebrada". ${ }^{44}$ Hoje, além de frequentar e se apresentar no Sarau da Brasa, ela e seus amigos organizam outros saraus em centros culturais da região. Mari se diz "apaixonada pela Brasilândia" e defende que "é importante estar na periferia”, já que eles são "marginalizados demais" e, por isso, "precisa criar um contato bacana" entre os vizinhos.

Assim, os saraus constituem-se como espaços fundamentais para a politização do cotidiano desses jovens e para a construção de uma visão de mundo mais coletivista e voltada para a própria periferia. Em oposição à solução individual de "trabalhar e fazer faculdade" - central no espirito da Freguesia resumido acima - ela começou, a partir da experiência cultural, a "olhar para o lado", valorizar a própria região e reproduzir aquela iniciativa com o intuito de ampliar a sociabilidade local e possibilitar que mais pessoas tivessem acesso àquele canal. No entanto, foi em junho de 2013 que ela teve "acesso às manifestações":

Aí eu não parava mais, tava sempre participando. Foi assim que eu comecei a conhecer partido, comecei a pesquisar política, comecei a me politizar mais. Eu sempre tive uma ideia assim só que era aquela coisa mais... Eu sabia a minha

24 "Quebrada" é outra importante categoria nativa que alude não apenas aos problemas de suas regiões, mas também "à força e à coragem daqueles que dela fazem parte" (Pereira, 2010, p. 156). 
posição como mulher, eu sabia minha posição como LGBT, eu sabia minha posição como periférica, mas era somente isso. Eu não sabia da minha posição política ao todo: o que tá acontecendo? O que eles querem? O que é direita? Eu não conhecia isso. (Informação verbal) ${ }^{25}$

Mari me contou que a primeira manifestação da qual participou foi justamente em um dos dias em que houve uma pesada repressão policial, que ela denominou de "Quinta Sangrenta”. Ela decidiu participar da manifestação de última hora, uma professora a chamou e ela disse: "Mano, eu vou!":

Só que, mano, o bagulho foi muito louco, eles fizeram barricadas no Largo da Batata, fecharam a gente assim num círculo e eu tava aqui no fundo, aí eles viram, [tinha] polícia pra cá e aí a gente virou e tinha polícia aqui, na mesma hora "pau!", tomei o maior cacete. Jogaram bomba, saí passando mal. Aí aquilo foi o meu energético, falei: "Mano, eu quero mais!”. Quanto mais eu apanho de polícia assim, mais dá vontade de ir. (Informação verbal) ${ }^{26}$

A narração de Mari daquele episódio aponta para outras questões relevantes que aproximam o modo de vida, a visão de mundo e as aspirações dos jovens moradores das periferias com a realidade desenvolvida nas lutas políticas mais recentes: a resposta repressora do Estado às demandas apresentadas, mesmo sob governos progressistas, e a associação da violência policial nas manifestações com a violência policial nas periferias que estimulam esses jovens a lutar com ainda mais ímpeto.

Mari compartilha da visão negativa a respeito da polícia que a maioria dos jovens das periferias apresentam

\footnotetext{
25 Declaração fornecida por Mari, de 17 anos, em entrevista na Brasilândia, em São Paulo, em outubro de 2016.

${ }^{26}$ Declaração fornecida por Mari, de 17 anos, em entrevista na Brasilândia, em São Paulo, em outubro de 2016.
} 
atualmente. Desse modo, a violência policial contra manifestantes é associada à violência policial que esses jovens sofrem frequentemente, o que contribui de forma central para a politização da realidade cotidiana desses jovens. Assim, a repressão policial acabou funcionando como um "energético", não apenas para ela, mas para as manifestações de junho de 2013 como um todo. ${ }^{27}$ Nesse sentido, os gritos e palavras de ordem que pedem o fim da polícia militar são, com frequência, os mais lembrados por vários dos meus interlocutores que participaram de manifestações recentes. A violência, vista como muitas vezes antipolítica, é fonte de politização nesse contexto, tanto por suas conexões com os agentes estatais que são parte e parcela de sua produção, quanto por seu potencial de gerar ou galvanizar a ação coletiva (Auyero, 2015).

Dessa forma, a negação do direito político de protestar encontrou eco na negação dos direitos civis que esses jovens enfrentam cotidianamente, uma vez que o agente dessa negação é o mesmo: as forças policiais do Estado, ou mais especificamente, a Polícia Militar. Assim, o enfrentamento público com as forças de segurança pública muitas vezes ocorre como resposta simbólica à negação de direitos e garantias fundamentais pelo Estado, seja de direitos civis no cotidiano, seja de direitos políticos nas manifestações. Desse modo, essas lutas têm um aspecto fundamental de reivindicarem o direito desses sujeitos a serem ouvidos em questões que lhes afetavam diretamente e, assim, dialogam com o desejo desses jovens das periferias de serem reconhecidos como cidadãos plenos, como detentores do "direito a ter direitos". ${ }^{28}$

\footnotetext{
27 Para uma reconstrução detalhada dos fatos que marcaram as manifestações de junho de 2013 em São Paulo e a respeito da importância da repressão policial para ampliação de participantes e de pautas daquelas manifestações, ver Judensnaider et al. (2013).

28 Para uma exploração mais aprofundada da ideia de "direito a ter direitos" entre os jovens das periferias, ver Fontes (2018a).
} 
Na experiência relatada por Mari, é possível notar como as manifestações de 2013, apesar de iniciadas por movimentos sociais que não tinham as periferias como espaço primordial de atuação, tiveram um importante impacto nessas regiões. ${ }^{29}$ De um lado, é marcante o impacto biográfico daquelas manifestações na vida de Mari e de vários outros jovens das periferias. Como apontam Bringel e Pleyers (2015, p. 11), as manifestações de junho produziram "'marcas' nos participantes, reforçando a propensão a que possam se engajar politicamente no futuro e podendo, ademais, transformar, no médio e longo prazo, suas identidades sociais e seus valores políticos".

Do ponto de vista coletivo e dos repertórios de ação, aquelas manifestações acabaram mostrando para esses jovens da periferia a possibilidade de recorrer a outras táticas de luta e reivindicação política, alternativos à via negocial dos canais de participação ou da cogestão das políticas 90 públicas por meio dos convênios, ou ainda, à via meramente eleitoral, que para eles sempre pareceu pouco atrativa e ineficiente e que foi marcante na geração anterior.

Em linha com esse novo ativismo que emergiu a partir de junho de 2013, está o processo de ocupações de escolas públicas que ocorreu no estado de São Paulo em 2015, contra um processo de "reorganização escolar" que o governo do Estado pretendia promover. ${ }^{30} \mathrm{~A}$ única escola que foi ocupada na Brasilândia foi justamente onde Mari estudava, a

\footnotetext{
29 De acordo com um survey aplicado nas duas regiões desta pesquisa, $11,5 \%$ dos moradores do Jardim Ângela e 5,8\% da Brasilândia participaram de alguma das mobilizações de junho de 2013. Conforme explicitado anteriormente, o survey contou com uma amostra aleatória de 391 residências nas duas regiões. Cumpre ressaltar que o objetivo desses dados não é determinar o tamanho preciso da adesão das periferias às manifestações de 2013, mas apontar que uma parcela significativa dos moradores das periferias se mobilizou naquela ocasião e assinalar, do ponto de vista etnográfico, as conexões entre essa mobilização e os coletivos culturais, entendidos aqui como "esferas públicas subalternas".

30 Para uma reconstrução detalhada do processo de ocupação de escolas em 2015, ver Campos et al. (2016).
} 
Escola Estadual Martin Egídio Damy, e ela teve participação ativa nesse processo. ${ }^{31}$

Assim como no caso de Mari, é bastante comum encontrar estudantes que estavam nas ocupações de escolas em 2015, que participavam dos saraus e cuja primeira experiência de mobilização coletiva havia sido em junho de 2013. Neste aspecto, cumpre salientar que, para esses jovens, bem como maior parte dos jovens das periferias que seguiram engajados politicamente, as manifestações de 2013 eram sempre lembradas como "do passe livre", "dos 20 centavos", "do Movimento Passe Livre (MPL)". Para eles, os atos de então foram essencialmente uma manifestação focada na questão da tarifa e a difusão posterior de pautas foi ignorada, esquecida, ou colocada na irrelevância. ${ }^{32}$

Assim, se em 2013, lutavam pelo direito ao transporte, em 2015 lutavam pelo direito à educação e em ambos os casos reivindicavam o direito de serem ouvidos sobre os rumos das políticas públicas. Nas duas ocasiões, os jovens que foram às ruas encontraram um Estado fechado a suas demandas e cuja resposta principal a suas reivindicações se deu pela via da repressão policial e pela desqualificação tecnocrática de suas demandas. Desse modo, os repertórios negociais de atuação política, que na avaliação dos próprios militantes já vinham rendendo ganhos cada vez mais marginais em termos de ampliação dos direitos sociais nos últimos anos, revelaram-se ineficientes tanto em 2013 quanto em 2015.

Tal como em 2013, os impactos das ocupações de 2015 vão muito além da vitória política contra o governo, como atesta Mari:

\footnotetext{
31 No Jardim Ângela foram oito escolas ocupadas ao todo. Além de Mari, conversei com vários colegas de escola dela, bem como com diversos outros alunos do Jardim Ângela ao longo e após o processo de ocupação. Para não tornar o relato demasiado longo, irei me restringir à experiência de Mari e de alguns de seus colegas.

32 Fato que também foi constatado por Campos et al. (2016).
} 
na verdade eu acho que foi o mais importante, eu acho que a ocupação é legal, o objetivo da ocupação é bacana, só que eu acho que a gente não vai conseguir deter um governo com isso, mas é legal assim, você vê o jovem entrando duma maneira, extremamente construído, conservador e ver ele saindo com outra cara. Toda semana tinha um debate, a gente recebeu visita lá do "Terça Afro", que é um evento que acontece aqui no Centro Cultural da Juventude (CCJ), onde faz a discussão [da questão] negra, os negros na periferia, o racismo, enfim... Machismo, movimento LGBT, movimento das mulheres em luta. Todos lá dentro, o tempo todo, conversando, construindo. (Informação verbal) ${ }^{33}$

Dessa forma, as marcas biográficas seguem presentes nessas manifestações recentes e assinalam resultados de dimensões dificilmente compreensíveis no curto prazo, uma vez que possibilitam a politização de aspectos do cotidiano desses sujeitos, como o machismo, o preconceito racial e a homofobia, e apontam para a possibilidade de formação de novos sujeitos políticos.

Finalmente, um último aspecto que merece destaque em termos de afinidades entre as manifestações recentes e o modo de vida reivindicado por alguns desses sujeitos nas periferias paulistanas está no caráter potencialmente descentralizado das mobilizações recentes. Essa descentralização dialoga diretamente com a cultura periférica que emerge em oposição ao espírito da Freguesia e que procurei expor acima. Trata-se, em última instância, da reivindicação desses sujeitos de obterem o reconhecimento enquanto cidadãos em seus próprios territórios, isto é, nas periferias. Algo para o qual os saraus de poesia apontam com proeminência.

Em junho de 2013 ocorreram alguns protestos descentralizados, entre eles uma manifestação na Avenida M'Boi

\footnotetext{
33 Declaração fornecida por Mari, de 17 anos, em entrevista na Brasilândia, em São Paulo, em outubro de 2016.
} 
Mirim, principal avenida que corta o Jardim Ângela. Aqueles que participaram dessa manifestação a relatam com especial orgulho, por terem dado visibilidade a uma avenida relativamente pouco conhecida fora de sua região. Do mesmo modo, durante as ocupações de 2015, uma estudante do Jardim Ângela me relatou com orgulho a fala de um professor de história que relembrava as lutas dos primeiros moradores da região e incentivava os alunos a "olhar pro nosso lado da periferia e começar a reivindicar ali”, pois em suas regiões conseguiriam mais espaço para suas próprias pautas.

Na Brasilândia, a expressão desse desejo de reconhecimento em seus próprios territórios apareceu de forma ainda mais contundente. Durante a ocupação da Escola Martin Egídio Damy, conversei com alguns dos alunos que lá estavam. Entre suas queixas sobre os movimentos sociais, estava a de que a grande maioria dos atos e manifestações políticas ocorrem sempre na região central da cidade. "Tudo [acontece] no Centro, sabe, tudo, tudo, porque só lá vai ser visto. Beleza, mas eu quero ser visto aqui. Vou ficar aqui!", me disse um aluno do $3^{\circ}$ ano do Ensino Médio.

A frase "mas eu quero ser visto aqui" não poderia ser mais significativa. Para ele, sua cidadania só será plenamente reconhecida - cidadania essa representada pela lógica do "ser visto” e, portanto, ser reconhecido como alguém que merece ter suas demandas ouvidas - quando ele for visto em sua própria condição de morador da periferia e na periferia. Ser visto sem precisar se deslocar para o centro da cidade é, portanto, parte essencial do processo de reconhecimento enquanto cidadãos plenos pelo qual lutam esses jovens, uma vez que o orgulho de ser da periferia é central em sua identidade.

\section{Considerações finais}

a geração da minha mãe [...] essa geração que pegou anos de 1980, teve aquela coisa de boom do consumo 
[nos anos 2000] ... eles ganhavam melhor, melhorou um pouco a situação de vida, [eles pensavam]: "vou comprar aquela televisão louca, vou morar num apartamento um pouco mais para lá e sair daqui”, o que já não é o caso da geração dos meus avós. Meu avô, apesar de agora ser um pouco desiludido assim, ele participava bastante de movimentos sociais para melhorar a região onde a gente mora. O lugar onde a gente mora não tinha luz, não tinha... tipo, não era regulamentado, tinha uma série de problemas e eles, junto com as pessoas da região, chegaram lá e começaram a morar e é o que fez tudo assim. Então, na geração dele, tinha esse negócio de melhorar o lugar e ficar. A geração da minha mãe queria ir embora, eu acho que a minha tá olhando de novo pra periferia, talvez porque os movimentos culturais tenham feito a gente olhar um pouco mais para cá e se identificar com isso, tipo: "Eu sou do Jardim Ângela” e isso significa alguma coisa que não é ruim, agora. (Informação verbal) ${ }^{34}$

$\mathrm{O}$ argumento aqui apresentado é, em alguma medida, resumido por Jéssica, moradora do Jardim Ângela e uma das interlocutoras dessa pesquisa. Ela compara o comportamento da geração de seus avós - pioneira na ocupação das periferias e que "participava bastante de movimentos sociais para melhorar a região" - com a geração de seus pais - que viveu o "boom do consumo", "melhorou um pouco a situação de vida" e almejava "morar num apartamento um pouco mais para lá e sair daqui" - e com a sua própria geração que estaria "olhando de novo pra periferia" devido aos "movimentos culturais", que teriam "feito a gente olhar um pouco mais para cá e se identificar com isso".

\footnotetext{
${ }^{34}$ Declaração fornecida por Jéssica, de 18 anos, em entrevista no Jardim Ângela, em São Paulo, em maio de 2016.
} 
Em conexão com essas mudanças em termos de modo de vida e aspirações individuais ou coletivas, procurou-se, neste texto, apontar as diferenças e continuidades em termos de formação política e cultural e mobilização social entre três gerações de moradores das periferias de São Paulo com destaque para a identificação de esferas públicas subalternas, nas quais uma cultura pública pode se formar. Para a primeira geração, formada no período de fechamento político e luta contra a ditadura militar, a Igreja Católica e as CEB exerceram importante papel para assegurar um espaço seguro de troca e formação política.

A segunda geração, marcada pela convergência perversa entre as políticas neoliberais e o desejo de atuação da sociedade civil organizada, formou-se e atuou politicamente em espaços institucionalizados como os partidos, ONGs e o próprio Estado.

Finalmente, a terceira geração, que cresceu sob a situação crítica da desestruturação do antigo modo de vida mais comunitário pelo aumento das buscas de soluções individuais para os problemas das periferias, passou a ver nos espaços de atuação oferecidos pelo Estado, ao invés de canais com potencial de ampliação de direitos, formas de limitação e confinamento da atuação política. Desse modo, os coletivos culturais tornaram-se o principal espaço de formação individual e coletiva e disseminação de uma mensagem e empoderamento e valorização identitárias do ser periférico. Da mesma forma, a ação direta descentralizada em manifestações, como em junho de 2013 ou na ocupação de escolas públicas em 2015, mostrou-se como um repertório de ação mais atrativo para essa nova geração, uma vez que os canais de diálogo com o Estado mostraram-se inócuos ou simplesmente fechados.

Na passagem da primeira para a segunda geração de movimentos sociais periféricos observamos uma continuidade quase que "natural" nas pautas e nas origens sociais 
e culturais dos sujeitos. Por outro lado, é possível observar profundas alterações em seus repertórios de atuação política. Dos atos públicos, do enfrentamento com a institucionalidade estatal e da contestação da tecnocracia, passou-se para um dinâmica de negociação, cooperação e parceria com o Estado. Agora, quando novos sujeitos políticos parecem emergir de uma dinâmica cultural que dialoga pouco com a realidade passada, um retorno modernizado àqueles repertórios mais contestatórios mostrou-se pragmaticamente necessário diante do fechamento tecnocrático e repressivo do Estado.

Cumpre ressaltar que não se quer afirmar aqui que o "espírito de comunidade", traduzido na cultura periférica, teria adquirido uma posição de prevalência quantitativa ou qualitativa sobre o "espírito da Freguesia", de caráter mais individualista e que tem na mobilidade social e territorial sua marca. O objetivo do artigo é apontar a existência dessa disputa pela hegemonia nas periferias e destacar as conexões concretas e observadas em termos etnográficos entre as manifestações políticas contemporâneas com os coletivos culturais e os saraus de poesia, apontando como estes têm funcionado como esfera pública subalterna, uma vez que trazem à tona questões públicas e são fundamentais na formação de novos sujeitos políticos. Ao lado do Estado e dos movimentos sociais, da religião e do "mundo do trabalho" (Feltran, 2014), ainda que também mediado pelo dinheiro e por uma perspectiva de afirmação pessoal (Tommasi, 2013), o "mundo da cultura" emerge como mais um espaço em que os sujeitos podem buscar justificação moral para suas ações, encontrar pontos em comum e se formar politicamente.

\section{Leonardo de Oliveira Fontes}

doutor em Sociologia pelo Instituto de Estudos Sociais e Políticos da Universidade Estadual do Rio de Janeiro (IESP/UERJ), pós-doutorando no International Interdisciplinary Postdoctoral 
Program (IPP) do Centro Brasileiro de Análise e Planejamento (Cebrap), bolsista da Fundação de Amparo à Pesquisa do Estado de São Paulo (Fapesp) pelo processo no 2019/13125-2.

\section{Bibliografia}

ALMEIDA, Ronaldo de. 2004. Religião na metrópole paulista. Revista Brasileira de Ciências Sociais, v. 19, n. 56, pp. 15-27.

ANTONIO, Gabriel Henrique Burnatelli de; LAHUERTA, Milton. 2014.

O neopentecostalismo e os dilemas da modernidade periférica sob o signo do novo desenvolvimentismo brasileiro. Revista Brasileira de Ciência Política, n. 14, pp. 57-82.

AUYERO, Javier. 2015. The politics of interpersonal violence in the urban periphery. Current Anthropology, v. 56, n. 11, pp. 169-79.

BOLTANSKI, Luc. 2016. Sociologia crítica e sociologia da crítica. In: VANDENBERGHE, Frédéric; VÉRAN, Jean François (orgs.). Além do habitus: teoria social pós-bourdieusiana. Rio de Janeiro: 7 Letras, pp. 129-154. BOLTANSKI, Luc; THÉVENOT, Laurent. 1999. The sociology of critical capacity. European journal of social theory, v. 2, n. 3, pp. 359-77.

BOURDIEU, Pierre. 2007. A distinção: crítica social do julgamento. São Paulo: Edusp.

BRINGEL, Breno; PLEYERS, Geoffrey. 2015. Junho de 2013... dois anos depois: polarização, impactos e reconfiguração do ativismo no Brasil. Nueva Sociedad. Disponível em: https://bit.ly/2XBHP9s. Acesso em: 21 jan. 2020.

BURAWOY, Michael. 1998. The extended case method. Sociological Theory, v. 16, n. 1, pp. 4-33.

CALDEIRA, Teresa Pires do Rio. 1984. A politica dos outros: o cotidiano dos moradores da periferia e o que pensam do poder e dos poderosos. São Paulo: Brasiliense.

CALDEIRA, Teresa Pires do Rio. 2000. Cidade de muros: crime, segregação e cidadania em São Paulo. São Paulo: Editora 34.

CALDEIRA, Teresa Pires do Rio. 2011. O rap e a cidade: reconfigurando a desigualdade em São Paulo. In: KOWARICK, Lúcio; MARQUES, Eduardo. (orgs.) São Paulo - novos percursos e atores: sociedade cultura e política. São Paulo: Editora 34, pp. 301-20.

CAMPOS, Antonia M.; MEDEIROS, Jonas; RIBEIRO, Márcio M. 2016. Escolas de luta. São Paulo: Veneta.

CARDOSO, Ruth. 1982. Duas faces de uma experiência. Novos Estudos Cebrap, v. 1, n. 2, pp. 53-58. 
CAVALCANTI, Mariana. 2009. Do barraco à casa: tempo, espaço e valor(es) em uma favela consolidada. Revista Brasileira de Ciências Sociais, v. 24, n. 69, pp. 69-80.

CEFAÏ, Daniel. 2009. Como nos mobilizamos? A contribuição de uma abordagem pragmatista para a sociologia da ação coletiva. Dilemas, v. 2, n. 4, pp. 11-48.

CEFAÏ, Daniel. 2017. Públicos, problemas públicos, arenas públicas... o que no ensina o pragmatismo (parte 1). Novos Estudos Cebrap, v. 36, n. 1, pp. 187-213.

D'ANDREA, Tiarajú Pablo. 2013. A formação dos sujeitos periféricos: cultura e política na periferia de São Paulo. Tese de Doutorado em Sociologia. São Paulo: USP.

DAGNINO, Evelina. 2004. Construção democrática, neoliberalismo e participação: os dilemas da confluência perversa. Política E Sociedade, v. 3, n. 5, pp. 139-164.

DEL ROIO, Marcos. 2017. Gramsci e as ideologias subalternas. In: DEL ROIO, Marcos. (org.). Gramsci: periferia e subalternidade. São Paulo: Edusp, pp. 41-64.

DURHAM, Eunice R. 1978. A caminho da cidade. 2. ed. São Paulo: Perspectiva.

DURHAM, Eunice R. 1988. A sociedade vista da periferia. In: KOWARICK, Lúcio (org.). As lutas sociais e a cidade: São Paulo: passado e presente. Rio de Janeiro: Paz e Terra, pp. 377-407.

FACHIN, Patricia. 2019. A expansão evangélica no Estado: do Executivo ao Judiciário. Entrevista especial com Ronaldo Almeida. São Leopoldo: Instituto Humanitas Unisinos. Disponível em: https://bit.ly/2waxtSE. Acesso em: 21 jan. 2020.

FELTRAN, Gabriel de Santis. 2011. Transformações sociais e políticas na periferia de São Paulo. In: KOWARICK, Lúcio; MARQUES, Eduardo. São Paulo: novos percursos e atores: sociedade cultura e política. São Paulo: Editora 34, pp. 123-144.

FELTRAN, Gabriel de Santis. 2014. Valor dos pobres: a aposta no dinheiro como mediação para o conflito social contemporâneo. Caderno CRH, v. 27, n. 72, pp. 495-512.

FONTES, Leonardo de Oliveira. 2018a. Do direito à cidade ao direito à periferia: transformações na luta pela cidadania nas margens da cidade. Plural, v. 25, n. 2, pp. 63-89.

FONTES, Leonardo de Oliveira. 2018b. O direito à periferia: experiências de mobilidade social e luta por cidadania entre trabalhadores periféricos de São Paulo. Tese de Doutorado em Sociologia. Rio de Janeiro: UERJ.

FONTES, Leonardo de Oliveira. 2018c. São Paulo nos anos 2000: segregação urbana e mobilidade social em termos de renda e 
escolaridade. Revista Brasileira de Estudos Urbanos e Regionais, v. 20, n. 2, pp. 304-324.

FRASER, Nancy. 1990. Rethinking the public sphere: a contribution to the critique of actually existing. Social Text, n. 25/26, pp. 56-80.

GÓES, Camila Massaro de. 2014. Existe um pensamento político subalterno? Um estudo sobre os subaltern studies: 1982-2000. Dissertação de Mestrado em Ciência Política. São Paulo: USP.

GOHN, Maria da Glória. 2011. Educação não formal e cultura política: impactos sobre o associativismo do terceiro setor. São Paulo: Cortez.

HABERMAS, Jürgen. 1984. Mudança estrutural da esfera pública: investigações quanto a uma categoria da sociedade burguesa. Rio de Janeiro: Tempo Brasileiro.

HALL, Stuart. 1981. Notes on deconstructing 'the popular'. DUNCOMBE, Stephen. Cultural resistance reader. New York: Verso.

JANUÁRIO, Adriano; CAMPOS, Antonia Malta; MEDEIROS, Jonas; RIBEIRO, Márcio Moretto. 2016. As ocupações de escolas em São Paulo (2015): autoritarismo burocrático, participação democrática e novas formas de luta social. Revista Fevereiro, v. 9, pp. 1-26.

JUDENSNAIDER, Elena; LIMA, Luciana; POMAR, Marcelo; ORTELLADO, Pablo. 2013. Vinte centavos: a luta contra o aumento. São Paulo: Veneta.

LIGUORI, Guido. 2017. Uso do termo "subalternos" em Gramsci e na atualidade. In: DEL ROIO, Marcos (org.). Gramsci: periferia e subalternidade. São Paulo: Edusp, pp. 23-40.

MACEDO, Márcio. 2014. “Periferia é periferia em qualquer lugar': de categoria espacial/analítica à categoria identitária/êmica no movimento hip-hop paulistano dos anos 1980 a 2000". Paper apresentado em III Seminário de Pesquisa da Fundação Escola de Sociologia e Política de São Paulo (FESPSP), São Paulo, 21 a 23 de outubro de 2011.

MANNHEIM, Karl. 1952. The problem of generations. In: MANNHEIM, Karl. Essays on the Sociology of Knowledge. London: Routledge, pp. 276-322.

MEDEIROS, Jonas. 2017. Movimentos de mulheres periféricas na Zona Leste de São Paulo: ciclos políticos, redes discursivas e contrapúblicos. Tese de Doutorado em Educação. Campinas: Unicamp.

MODONESI, Massimo. 2017. Da subalternidade ao subalternismo: uma crítica gramsciana aos Subaltern Studies. In: DEL ROIO, Marcos (org.). Gramsci: periferia e subalternidade. São Paulo: Edusp, pp. 89-106.

NASCIMENTO, Érica Peçanha do. 2010. A periferia de São Paulo: revendo discursos, atualizando o debate. Rua, v. 2, n. 16, pp. 111-128. 
NOVAES, Regina; ALVIM, Rosilene. 2014. Movimentos, redes e novos coletivos juvenis: um estudo sobre pertencimentos, demandas e políticas públicas de juventude. In: LOPES, José Sergio Leite; HEREDIA, Beatriz. Movimentos sociais e esfera pública: o mundo da participação, burocracias, confrontos, aprendizados inesperados. Rio de Janeiro: CBAE, pp. 269-302.

OLIVEIRA, Francisco de. 2007. Política numa era de indeterminação: opacidade e reencantamento. In: OLIVEIRA, Francisco de. A era da indeterminação. São Paulo: Boitempo, pp. 15-45.

OLIVEIRA, Francisco de. 2010. Hegemonia às avessas. In: OLIVEIRA, Francisco de; BRAGA, Ruy; RIZEK, Cibele. Hegemonia às avessas: economia, política e cultura na era da servidão financeira. São Paulo: Boitempo, pp. 21-27.

PEREIRA, Alexandre Barbosa. 2010. As marcas da cidade: a dinâmica da pixação em São Paulo. Lua Nova, n. 79, p. 143-162.

PERLATTO, Fernando. 2015. Seletividade da esfera pública e esferas públicas subalternas: disputas e possibilidades na modernização brasileira. Revista de Sociologia e Política, v. 23, n. 53, pp. 121-54.

PINHEIRO-MACHADO, Rosana; SCALCO, Lucia Mury. 2018. Da esperança ao ódio: Juventude, política e pobreza do lulismo ao bolsonarismo. São Leopoldo: Instituto Humanitas Unisinos.

SADER, Eder. 1988. Quando novos personagens entraram em cena: experiências, falas e lutas dos trabalhadores da Grande São Paulo (1970-80). Rio de Janeiro: Paz e Terra.

SCOTT, James C. 1990. Domination and the arts of resistance. New Haven and London: Yale University Press.

SEMERARO, Giovanni. 2017. O protagonismo das periferias e dos subalternos na alternativa desenhada por Gramsci. In: DEL ROIO, Marcos (org.). Gramsci: periferia e subalternidade. São Paulo: Edusp, pp. 107-124.

SILVA, Lívia Lima da. 2017. A literatura fora do lugar: a constituição de poetas e escritores nos saraus das periferias de São Paulo. Dissertação de Mestrado em Estudos Culturais. São Paulo: USP.

SILVA, Luiz Antonio Machado da. 2002. Da informalidade à empregabilidade (reorganizando a dominação no mundo do trabalho). Cadernos CRH, v. 15, n. 37, pp. 81-109.

SINGER, André. 2012. Os sentidos do Lulismo: reforma gradual e pacto conservador. São Paulo: Companhia das Letras.

TELLES, Vera da Silva. 2006. Mutações do trabalho e experiência urbana. Tempo Social, v. 18, n. 1, pp. 173-195. 
THOMPSON, Edward Palmer. 1966. The making of the English working class. New York: Vintage Book.

TILLY, Charles. 1978. From mobilization to revolution. Massachusetts: Addison-Wesley Publishing Company.

TOMMASI, Livia de. 2013. Culturas de periferia: entre o mercado, os dispositivos de gestão e o agir político. Política $\mathcal{E}^{\circ}$ Sociedade, v. 12, n. 23, pp. 11-34.

WACQUANT, Loïc. 2007. Territorial stigmatization in the age of advanced marginality. Thesis Eleven, v. 91, n. 1, pp. 66-77.

ZALUAR, Alba; LEAL, Maria Cristina. 1998. Para não dizer que não falei de samba: os enigmas da violência no Brasil. In: SCHWARCZ, Lilia Moritz (org.). História da vida privada no Brasil: contrastes da intimidade. São Paulo: Companhia das Letras, pp. 245-303.

ZALUAR, Alba. 2000. A máquina e a revolta: as organizações populares e o significado da pobreza. 2. ed. São Paulo: Brasiliense. 


\section{DA FORMAÇÃO CULTURAL À MOBILIZAÇÃO SOCIAL: ESPAÇOS DE FORMAÇÃOO E MOBILIZAÇÃO AO LONGO DE TRÊS GERAÇÕES NAS PERIFERIAS DE SÃO PAULO}

\section{LEONARDO DE OLIVEIRA FONTES}

Resumo: O objetivo deste artigo é analisar empiricamente como uma "cultura pública" foi formada e tornou-se capaz de dar forma e material a mobilizações coletivas nas periferias de São Paulo. Para tanto, o artigo dá um passo atrás em relação ao que é tradicionalmente entendido como análise dos movimentos sociais e da ação coletiva e se concentra nas experiências de formação individual e coletiva dos sujeitos políticos. A pesquisa aqui apresentada baseia-se em uma etnografia realizada em dois bairros da periferia de São Paulo e em uma análise histórica sobre a luta política de três gerações de moradores das periferias da cidade. Assim, além de explorar as mudanças históricas em termos de repertórios de ação, o artigo analisa as conexões entre o modo de vida dos sujeitos, os espaços de deliberações e de formação política - aqui entendidos como "esferas públicas subalternas" - e ações coletivas nas periferias de São Paulo para cada uma das gerações estudadas. Argumenta-se que para a primeira geração, os espaços prioritários de formação estavam situados em torno da Igreja Católica, sobretudo nas Comunidades Eclesiais de Base. Para os pertencentes à segunda geração, os espaços mais relevantes foram as próprias instituições formadas a partir da mobilização dos anos anteriores com destaque para ONG e canais oficiais de participação popular. Finalmente, para a terceira geração, coletivos culturais e principalmente os saraus de poesia ganham destaque.

Palavras-chave: Mobilização Coletiva; Periferia; Movimentos Sociais; Cultura; São Paulo. 


\section{FROM CULTURAL FORMATION TO SOCIAL MOBILIZATION: SPACES FOR FORMATION AND MOBILIZATION OVER THREE GENERATIONS IN THE SÃO PAULO OUTSKIRTS}

Abstract: This paper analyzes empirically how a "public culture" was formed and became capable of giving form and material to collective mobilizations in the São Paulo outskirts. For such, this article takes a step backwards from what is traditionally understood as an analysis of social movements and collective actions and focuses on the subjects' formational experiences. The research presented here is based on an ethnography performed in two districts on the São Paulo outskirts, as well as on a historical analysis concerning the political struggle of three generations of outskirt residents. Thus, in addition to exploring historical changes in terms of repertoires of action, this paper analyzes the connections between the subjects' way of life, spaces for deliberation and political formation - here understood as "subaltern public spheres" - and collective actions in the outskirts of São Paulo for each generation studied. The priority spaces of formation for the first generation are argued to be related with the Catholic Church, especially in the Base Ecclesiastical Communities. For those belonging to the second generation, the most relevant spaces were the institutions themselves formed from the mobilization of previous years, with emphasis on NGOs and official channels for popular participation. Lastly, for the third generation, cultural collectivities and especially poetry soirees were prominent.

Keywords: Collective Mobilization; Outskirt; Social Movements; Culture; São Paulo.

Recebido: 17/01/2019 Aprovado: 23/01/2020 